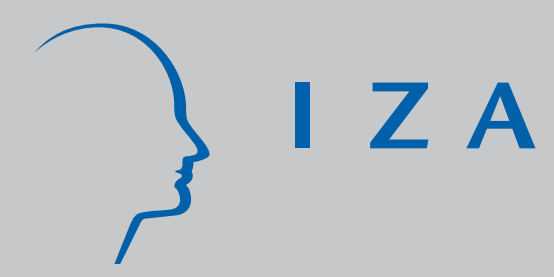

IZA DP No. 3830

Wage Differentials across Sectors in Europe: An East-West Comparison

Iga Magda

François Rycx

Ilan Tojerow

Daphné Valsamis

November 2008 


\title{
Wage Differentials across Sectors in Europe: An East-West Comparison
}

\author{
Iga Magda \\ Polish Ministry of Labour and Social Policy \\ François Rycx \\ DULBEA, Université Libre de Bruxelles \\ and IZA \\ Ilan Tojerow \\ DULBEA, Université Libre de Bruxelles \\ and IZA \\ Daphné Valsamis \\ DULBEA, Université Libre de Bruxelles
}

Discussion Paper No. 3830
November 2008

IZA

P.O. Box 7240

53072 Bonn

Germany

Phone: +49-228-3894-0

Fax: +49-228-3894-180

E-mail: iza@iza.org

Any opinions expressed here are those of the author(s) and not those of IZA. Research published in this series may include views on policy, but the institute itself takes no institutional policy positions.

The Institute for the Study of Labor (IZA) in Bonn is a local and virtual international research center and a place of communication between science, politics and business. IZA is an independent nonprofit organization supported by Deutsche Post World Net. The center is associated with the University of Bonn and offers a stimulating research environment through its international network, workshops and conferences, data service, project support, research visits and doctoral program. IZA engages in (i) original and internationally competitive research in all fields of labor economics, (ii) development of policy concepts, and (iii) dissemination of research results and concepts to the interested public.

IZA Discussion Papers often represent preliminary work and are circulated to encourage discussion. Citation of such a paper should account for its provisional character. A revised version may be available directly from the author. 
IZA Discussion Paper No. 3830

November 2008

\section{ABSTRACT \\ Wage Differentials across Sectors in Europe: An East-West Comparison ${ }^{*}$}

This study compares the structure and determinants of inter-industry wage differentials in Eastern and Western European countries (namely Belgium, Italy, the Netherlands, Norway, Portugal and Spain compared with Latvia, Lithuania, the Czech Republic, Poland and Slovakia). To do so, we use a unique harmonised, linked employer-employee data set, the 2002 European Structure of Earnings Survey. Findings show substantial differences in earnings across sectors in all countries, even when controlling for a wide range of employee, job and employer characteristics. The hierarchy of sectors in terms of wages appears to be quite similar in Eastern and Western European countries. Among high-wage sectors, we find the energy (coke, petroleum, gas, electricity and nuclear power), chemical, financial and computer industries. In contrast, it is in the traditional sectors (wood and cork industry, textile, clothing and leather industry, hotels and restaurants, and retailing) that wages are lowest. Further results suggest that the dispersion of inter-industry wage differentials fluctuates considerably across countries. It is relatively small in Norway and Belgium, large in the Netherlands, Italy, Spain, Poland and the Czech Republic, and very large in Portugal, Latvia, Lithuania and Slovakia. Our findings support the hypothesis of a negative relationship between the dispersion of inter-industry wage differentials and a country's degree of corporatism.

JEL Classification: J31, J51

Keywords: inter-industry wage differentials, collective bargaining, Europe, matched employer-employee data

Corresponding author:

Ilan Tojerow

Department of Applied Economics (DULBEA)

Free University of Brussels

50 Avenue F.D. Roosevelt

B-1050 Brussels

Belgium

E-mail: itojerow@ulb.ac.be

This paper is produced as part of a research contract for the European Commission (DG Employment, No. VT/2005/92) entitled "Study and Conference on European Labour Market Analysis using Firm-Level Panel Data and Linked Employer-Employee Data" (http://cep.Ise.ac.uk/leed/). The authors are grateful to participants of the Annual Meeting of the Society of Labor Economists (Columbia University, New York, May 8-9, 2008) and the Annual Meeting of the European Association of Labour Economists (Amsterdam, September 19-20, 2008) for useful comments and suggestions. The usual disclaimer applies. 


\section{Introduction}

The empirical debate about the causes of earnings inequalities was reopened at the end of the 1980s by an article by Krueger and Summers (1988). The authors highlighted the fact that the structure of wages in the US was not compatible with the neo-classical model, according to which wage differentials in equilibrium are explained either through differences in the quality of the labour force - measured in terms of productive capacity - or by so-called compensating differences. In other words, they showed that wage disparities persisted between agents with apparently identical individual characteristics and working conditions, employed in different sectors. Since then, similar results have been obtained for numerous industrialised countries (Lucifora, 1993; Ferro-Luzzi, 1994; Vainiomäki et al., 1995; Araï et al., 1996; Hartog et al., 1997, 1999; Plasman et al., 2006; Gannon et al., 2007). Accordingly, the existence of sectoral effects has become a stylised fact in the economic literature. There is, moreover, general agreement on the fact that these effects are persistent (Gittleman et al., 1993; Kouwenberg et al., 1999) closely correlated from one country to another (Helwege, 1992; Lucifora, 1993; Erdil et al., 2001), and of varying dimensions in the industrialised countries (Hartog et al., 1997). A number of studies, except that of Björklund et al. (2007), suggest in addition that sectoral effects are significantly weaker in strongly corporatist countries, regardless of the period studied (Edin and Zetterberg, 1992; Zweimüller and Barth, 1994; Kahn, 1998; Teulings and Hartog, 1998; Hartog et al., 2000; Gannon et al., 2007). ${ }^{1}$ Teulings and Hartog (1998), for example, report that from the most to the least corporatist country the dispersion in industry wage premia increases roughly at a ratio of 1:4. Cross-country comparisons of inter-industry wage differentials must, however, be considered with caution. The point is that results obtained for different countries are seldom strictly comparable because of differences in the specification of the wage equation, the sectoral nomenclature used, the field covered by the data or the period under investigation.

Overall, the existence of sectoral wage premia increasingly cast doubt on the assumption of a perfectly competitive labour market. Indeed, they suggest that individual wages are not solely determined by personal productive characteristics and task descriptions but also by the features of the employers in each sector. Nevertheless, many uncertainties remain. One of these derives from the fact that the unobserved quality of the labour force might not be randomly distributed among industries. In other words, high-paying industries might simply be those in which the unmeasured labour quality is the highest. Using the 1984 and 1986 Displaced Workers Surveys, Gibbons and Katz (1992) show for the US that the magnitude of the industry wage differentials is almost undiminished when estimating wage equations in first differences rather than in levels. Their findings thus indicate that the workers' sectoral affiliation does matter. The unobserved quality explanation has also been tested by Martins (2004). Applying quantile regressions to a Portuguese matched employer-employee data set from 1995, the author rejects the hypothesis that high-wage industries draw disproportionately more

1 The concept of corporatism, borrowed from political science, resembles the level of centralisation of collective bargaining, as well as the degree of coordination between the social partners. However, as this concept has not been defined in one single way, there are differences of opinion as to the relative position of the industrialised countries on the scale of corporatism (OECD, 1997, 2004). The Scandinavian countries and Austria are nevertheless always in the category of strongly corporatist countries, whereas the US and Canada are invariably at the bottom of the ranking. At the present time, Eastern European countries are ranked low on the corporatism scale. 
on high-ability workers. Therefore, he suggests that non-competitive forces may play an important role in the wage determination process. In contrast, findings of Goux and Maurin (1999) and Abowd et al. (1999) show that individual fixed effects explain a large fraction of the estimated inter-industry wage differentials in France. A similar result has been found by Benito (2000) using individual-level data from the British Household Panel Survey for 1991 and 1994, respectively. All in all, there is no consensus regarding the exact scale of the industry wage premia. Moreover, while various explanations based on efficiency wage mechanisms or rent sharing have been put forward (Krueger and Summers, 1988; Thaler, 1989; Lindbeck and Snower, 1990; Walsh, 1999; Benito, 2000; Plasman et al., 2006), the existence of industry wage differentials remains a complex and unresolved puzzle.

In this paper, we compare the structure and determinants of inter-industry wage differentials in Eastern and Western European countries (Belgium, Italy, the Netherlands, Norway, Portugal and Spain compared with Latvia, Lithuania, the Czech Republic, Slovakia and Poland). To do so, we use a unique harmonised, linked employer-employee data set, the 2002 European Structure of Earnings Survey (ESES). While matched employer-employee data sets are now available for a number of individual countries, to the best of our knowledge the ESES provides the only multicountry data set with matched employer-employee data. This survey contains detailed information, provided by the management of establishments, both on individual workers (for example, gross hourly wages, bonuses, age, education, tenure, sex, occupation, employment contract, working time) and employers' characteristics (for example, sector of activity, size of establishment, level of wage bargaining, region). Although the effect of sectoral affiliation on workers' wages has been a topic of great interest, the evidence for Eastern European countries is quite limited (Chase, 1998; Newell, 2001; Geishecker and Haisken-DeNew, 2002). Moreover, little is known on how inter-industry wage differentials differ between Eastern and Western European countries. This paper aims to fill this gap by exploring the following questions:

(1) How big and significant are inter-industry wage differentials in Eastern European countries, namely the Czech Republic, Latvia, Lithuania, Slovakia and Poland? Can they be explained by the sectoral diversity in employee, job and employer characteristics?

(2) Are the sectors offering high and low wages similar in Eastern and Western European countries?

(3) Does the dispersion of inter-industry wage differentials vary across European countries? Is it significantly different in Eastern European countries? Is it correlated with national collective bargaining characteristics?

The remainder of this paper is organised as follows. Section 2 describes the data used in the paper and presents summary statistics. Sections 3 to 5 present the methodology and the empirical results. The last section concludes. 


\section{Description of the data}

The present study is based on the 2002 European Structure of Earnings Survey, gathered by Eurostat. This harmonised survey contains a wealth of information, provided by the management of establishments, both on the characteristics of the latter (for example, sector of activity, number of workers, level of collective wage bargaining, region) and on the individuals working there (for example, age, education, tenure, gross earnings, paid hours, sex, occupation, bonuses). It is representative of all establishments employing at least ten workers and whose economic activities fall within sections $\mathrm{C}$ to $\mathrm{K}$ of the NACE Rev. 1 nomenclature. $^{2}$

Table 1 depicts the means of selected variables across European countries, namely for the Czech Republic, Latvia, Lithuania, Slovakia, Poland, Belgium, Italy, the Netherlands, Norway, Portugal and Spain. Gross hourly wages (including bonuses) are found to be much higher in Western European countries (21.5 euros in Norway vs 1.5 euros in Latvia and Lithuania). In contrast, workers appear to have a higher level of education in Eastern Europe. Indeed, while the percentage of individuals having at most a primary degree or no degree varies in Western Europe from $4.9 \%$ in Norway to $56.8 \%$ in Portugal, this percentage falls to less than 1\% in Eastern Europe. In all countries, the vast majority of workers are employed on a full-time basis with a permanent contract. But the incidence of part-time employment reaches more than $20 \%$ in the Netherlands and Norway, and more than $10 \%$ in Latvia, Lithuania, Belgium and Italy. The proportion of workers with a fixed-term contract stands at more than $20 \%$ in Spain and Portugal, and at more than $10 \%$ in the Netherlands, the Czech Republic and Lithuania. Also noteworthy is that collective bargaining institutions differ significantly in the West and East of Europe. While the majority of workers in Western Europe have their wages solely determined by national and/or sectoral collective agreements (the percentage varies from $68.9 \%$ in Belgium to $93.1 \%$ in Italy), ${ }^{3}$ the most widespread level of collective bargaining in Eastern Europe is the establishment level. Moreover, many Eastern European workers are not covered by collective agreements (this percentage varies from 34.9\% in the Czech Republic to $81.1 \%$ in Latvia and Lithuania).

2 It thus covers the following sectors: i) mining and quarrying (C), ii) manufacturing (D), iii) electricity, gas and water supply (E), vi) construction (F), iv) wholesale and retail trade, repair of motor vehicles, motorcycles and personal and household goods (G), v) hotels and restaurants (H), vi) transport, storage and communication (I), financial intermediation (J), and vii) real estate, renting and business activities (K).

3 This variable is missing for Norway and the Netherlands. 
Table 1: Means of selected variables (weighted sample)

\begin{tabular}{|c|c|c|c|c|c|c|c|c|c|c|c|}
\hline Variables & $\mathbf{C Z}$ & LV & $\mathbf{L T}$ & SK & PL & BE & IT & NL & No & PT & ES \\
\hline Gross hourly wage & $3.0 €$ & $1.5 €$ & $1.5 €$ & $2.4 €$ & $2.8 €$ & $17.1 €$ & $11.0 €$ & $16.3 €$ & $21.5 €$ & $5.8 €$ & $8.6 €$ \\
\hline \multicolumn{12}{|l|}{ Employee characteristics } \\
\hline Female & $40.1 \%$ & $44.1 \%$ & $42.8 \%$ & $39.9 \%$ & $37.7 \%$ & $28.7 \%$ & $33.3 \%$ & $32.6 \%$ & $34.0 \%$ & $40.1 \%$ & $32.4 \%$ \\
\hline Age & 40.5 & 39.4 & 38.7 & 38.6 & 37.8 & 38.2 & 38.5 & 37.4 & 38.8 & 36.8 & 36.9 \\
\hline Primary or no degree & $0.3 \%$ & $0.3 \%$ & $0.7 \%$ & $0.0 \%$ & $0.2 \%$ & $8.1 \%$ & $7.4 \%$ & $9.3 \%$ & $4.9 \%$ & $56.8 \%$ & $28.7 \%$ \\
\hline Lower secondary & $11.4 \%$ & $10.1 \%$ & $7.2 \%$ & $8.1 \%$ & $10.7 \%$ & $26.5 \%$ & $43.2 \%$ & $23.2 \%$ & $11.5 \%$ & $18.0 \%$ & $30.6 \%$ \\
\hline General upper secondary & $74.2 \%$ & $32.6 \%$ & $41.2 \%$ & $74.0 \%$ & $71.5 \%$ & $37.7 \%$ & $37.6 \%$ & $43.5 \%$ & $61.6 \%$ & $16.9 \%$ & $17.3 \%$ \\
\hline type & $3.4 \%$ & $38.3 \%$ & $31.4 \%$ & $3.9 \%$ & $3.8 \%$ & $16.0 \%$ & $3.9 \%$ & $7.2 \%$ & $6.6 \%$ & $2.2 \%$ & $9.0 \%$ \\
\hline $\begin{array}{l}\text { University and non- } \\
\text { university higher education }\end{array}$ & $10.4 \%$ & $18.5 \%$ & $19.5 \%$ & $13.9 \%$ & $13.7 \%$ & $10.8 \%$ & $7.3 \%$ & $16.5 \%$ & $14.9 \%$ & $6.0 \%$ & $14.3 \%$ \\
\hline Post-graduate & $0.3 \%$ & $0.2 \%$ & $0.1 \%$ & $0.3 \%$ & & $0.8 \%$ & $0.5 \%$ & $0.3 \%$ & $0.3 \%$ & $0.0 \%$ & $0.1 \%$ \\
\hline $\begin{array}{l}\text { Prior potential experience } \\
\text { Seniority in the current }\end{array}$ & 14.6 & 16.6 & 14.8 & 12.2 & 18.6 & 10.7 & 10.5 & 12.5 & 14.6 & 15.3 & 14.0 \\
\hline company & 8.1 & 3.7 & 4.9 & 8.3 & 7.2 & 10.0 & 11.4 & 7.4 & 6.2 & 7.1 & 7.0 \\
\hline \multicolumn{12}{|l|}{ Job characteristics } \\
\hline Open-ended contract & $84.3 \%$ & $92.9 \%$ & $89.5 \%$ & $85.2 \%$ & & $95.3 \%$ & $94.9 \%$ & $87.5 \%$ & $98.4 \%$ & $71.9 \%$ & $72.9 \%$ \\
\hline Fixe-term contract & $12.0 \%$ & $7.1 \%$ & $10.5 \%$ & $9.6 \%$ & & $4.1 \%$ & $3.5 \%$ & $12.5 \%$ & $1.1 \%$ & $21.4 \%$ & $26.8 \%$ \\
\hline Apprentice/Trainee contact & $0.0 \%$ & $0.0 \%$ & $0.0 \%$ & $0.0 \%$ & & $0.1 \%$ & $1.2 \%$ & $0.0 \%$ & $0.5 \%$ & $0.0 \%$ & $0.3 \%$ \\
\hline Other & $3.7 \%$ & $0.0 \%$ & $0.0 \%$ & $5.2 \%$ & & $0.5 \%$ & $0.3 \%$ & $0.0 \%$ & $0.0 \%$ & $6.6 \%$ & $0.0 \%$ \\
\hline Full-time & $93.3 \%$ & $87.5 \%$ & $88.1 \%$ & $97.3 \%$ & & $87.1 \%$ & $87.1 \%$ & $70.4 \%$ & $79.2 \%$ & $96.4 \%$ & $90.0 \%$ \\
\hline $\begin{array}{l}\text { Part-time } \\
\text { Earnings related to }\end{array}$ & $6.7 \%$ & $12.5 \%$ & $11.9 \%$ & $2.7 \%$ & & $12.9 \%$ & $12.9 \%$ & $29.6 \%$ & $20.8 \%$ & $3.6 \%$ & $10.0 \%$ \\
\hline $\begin{array}{l}\text { overtime } \\
\text { Earnings related to shift }\end{array}$ & $46.5 \%$ & $2.3 \%$ & $3.0 \%$ & $21.9 \%$ & $1.4 \%$ & $2.3 \%$ & $36.6 \%$ & $12.7 \%$ & $41.2 \%$ & $7.4 \%$ & $6.9 \%$ \\
\hline work & $56.1 \%$ & $2.9 \%$ & $18.3 \%$ & $24.7 \%$ & & $19.8 \%$ & $13.1 \%$ & $5.8 \%$ & $35.6 \%$ & $0.0 \%$ & $14.6 \%$ \\
\hline \multirow{2}{*}{\multicolumn{12}{|c|}{$\begin{array}{l}\text { Employer characteristics } \\
\text { Size of the establishment: }\end{array}$}} \\
\hline & & & & & & & & & & & \\
\hline 10 - 49 workers & $21.3 \%$ & $39.7 \%$ & $30.6 \%$ & $22.8 \%$ & $29.4 \%$ & $9.3 \%$ & $36.5 \%$ & $28.0 \%$ & $37.5 \%$ & $43.8 \%$ & $38.5 \%$ \\
\hline 50 - 249 workers & $36.5 \%$ & $33.6 \%$ & $34.9 \%$ & $25.2 \%$ & $35.5 \%$ & $31.1 \%$ & $25.3 \%$ & $25.1 \%$ & $27.0 \%$ & $29.1 \%$ & $24.3 \%$ \\
\hline 250 - 499 workers & $11.1 \%$ & $9.6 \%$ & $9.7 \%$ & $9.9 \%$ & $12.2 \%$ & $19.5 \%$ & $8.6 \%$ & $9.1 \%$ & $10.8 \%$ & $8.9 \%$ & $8.4 \%$ \\
\hline 500 - 999 workers & $13.4 \%$ & $7.0 \%$ & $9.6 \%$ & $12.7 \%$ & $8.5 \%$ & $16.1 \%$ & $7.4 \%$ & $6.9 \%$ & $9.2 \%$ & $6.1 \%$ & $6.5 \%$ \\
\hline > 1000 workers & $17.7 \%$ & $10.1 \%$ & $15.2 \%$ & $29.4 \%$ & $14.4 \%$ & $24.0 \%$ & $22.1 \%$ & $30.9 \%$ & $15.5 \%$ & $12.1 \%$ & $22.3 \%$ \\
\hline $\begin{array}{l}\text { Level of wage bargaining: } \\
\text { National and/or sectoral } \\
\text { level }\end{array}$ & $12.1 \%$ & $0.4 \%$ & $0.0 \%$ & $7.7 \%$ & & $68.9 \%$ & $93.1 \%$ & & & $74.6 \%$ & $81.6 \%$ \\
\hline Company level & $53.0 \%$ & $18.5 \%$ & $18.9 \%$ & $45.3 \%$ & & $30.7 \%$ & $0.0 \%$ & & & $3.4 \%$ & $16.5 \%$ \\
\hline Other & $0.0 \%$ & $0.0 \%$ & $0.0 \%$ & $4.5 \%$ & & $0.0 \%$ & $0.0 \%$ & & & $19.2 \%$ & $1.8 \%$ \\
\hline No bargaining & $34.9 \%$ & $81.1 \%$ & $81.1 \%$ & $42.5 \%$ & & $0.4 \%$ & $6.9 \%$ & & & $2.7 \%$ & $0.0 \%$ \\
\hline Number of observations & 598493 & 142045 & 71608 & 252601 & 293571 & 98023 & 75179 & 31873 & 477662 & 52725 & 172437 \\
\hline
\end{tabular}

\section{Methodology}

The methodology that has been adopted to estimate the magnitude and dispersion of inter-industry wage differentials is consistent with that of Krueger and Summers (1988). However, the standard errors of the industry wage differentials have been corrected according to Zanchi (1998). Overall, this strategy rests upon the estimation, for each country, of the following Mincer-type (1974) wage equation:

$$
\ln w_{i}=\alpha+\sum_{j=1}^{J} \beta_{j} X_{j, i}+\sum_{k=1}^{K} \gamma_{k} Y_{k, i}+\sum_{l=1}^{L} \delta_{l} Z_{l, i}+\sum_{m=1}^{M} \psi_{m} S_{m, i}+\varepsilon_{i}
$$


where $w_{i}$ represents the gross hourly wage of the individual $i$ (for $i=1, \ldots, \mathrm{N}$ ); $X$ is the vector of the individual characteristics of the workers (6 dummy variables showing the highest completed level of education; prior potential experience, its square and its cube; seniority within the current company and its square; and a dummy for gender); $Y$ is a vector of job characteristics (3 dummies for the type of contract; a dummy for part-time work; an indicator showing whether the individual is paid a bonus for shift work, nighttime and/or weekend work; a dummy for extra paid hours; and 23 occupational dummies); $Z$ contains employer characteristics (4 dummies indicating the size of the establishment; between 2 and 3 dummies for the level of wage bargaining; and between 2 and 6 dummies indicating the region where the establishment is located); $S$ comprises dummy variables relating to the sectoral affiliation of the individuals (at the NACE two-digit level); $\alpha$ is the intercept; $\beta, \gamma, \delta$ and $\psi$ are the parameters to be estimated and $\varepsilon_{i}$ is an error term.

In accordance with Zanchi (1998), the variability in industry wage differentials has been measured by the standard deviation of the industry wage premia, adjusted for least squares sampling error and weighted by sectoral employment shares. This summary statistic, further referred to in the text as WASD (weighted adjusted standard deviation), corresponds to the following expression:

WASD $\left(d_{m}\right)=\sqrt{\sum_{m=1}^{M+1} \bar{p}_{m}\left[d_{m}-\frac{\sum_{m=1}^{M+1} d_{m}}{M+1}\right]^{2}-\frac{\sum_{m=1}^{M+1} \operatorname{var}\left(d_{m}\right)}{M+1}+\frac{\sum_{m=1}^{M+1} \sum_{l=1}^{M+1} \operatorname{cov}\left(d_{m}, d_{l}{ }^{*}\right)}{(M+1)^{2}}}$

\section{Wage regressions}

Before embarking upon the analysis of the effects of workers' sectoral affiliation on wages, we briefly discuss the results from equation (1) that has been estimated for each country by OLS with White (1980) heteroscedasticity-consistent standard errors.

Results from our wage regressions, presented in Table 2, are quite satisfactory. Indeed, a substantial part of the total variation in individual hourly wages is explained by the regression model (the adjusted $\mathrm{R}^{2}$ varies between approximately $40 \%$ in Latvia and $64 \%$ in Belgium). Moreover, most regression coefficients are significant and have the expected sign. In line with human capital theory, we find that the level of education exercises a substantial positive influence upon wages in all countries. However, the magnitude of the return on education is quite variable. Notice, for example, that the wage differential between someone with a primary education qualification and someone with a postgraduate degree varies from $39.1 \%$ in Norway to $99.4 \%$ in the Czech Republic. ${ }^{4}$ Overall, the return on education does not appear to be significantly different in Eastern and Western European countries.

4 Technically, this figure is obtained by taking the antilog (to base e) of the estimated dummy coefficient from which 1 is subtracted (x 100). For more details see Gujarati (1995: 525). 
Table 2: Wage regressions (OLS with robust standard errors)

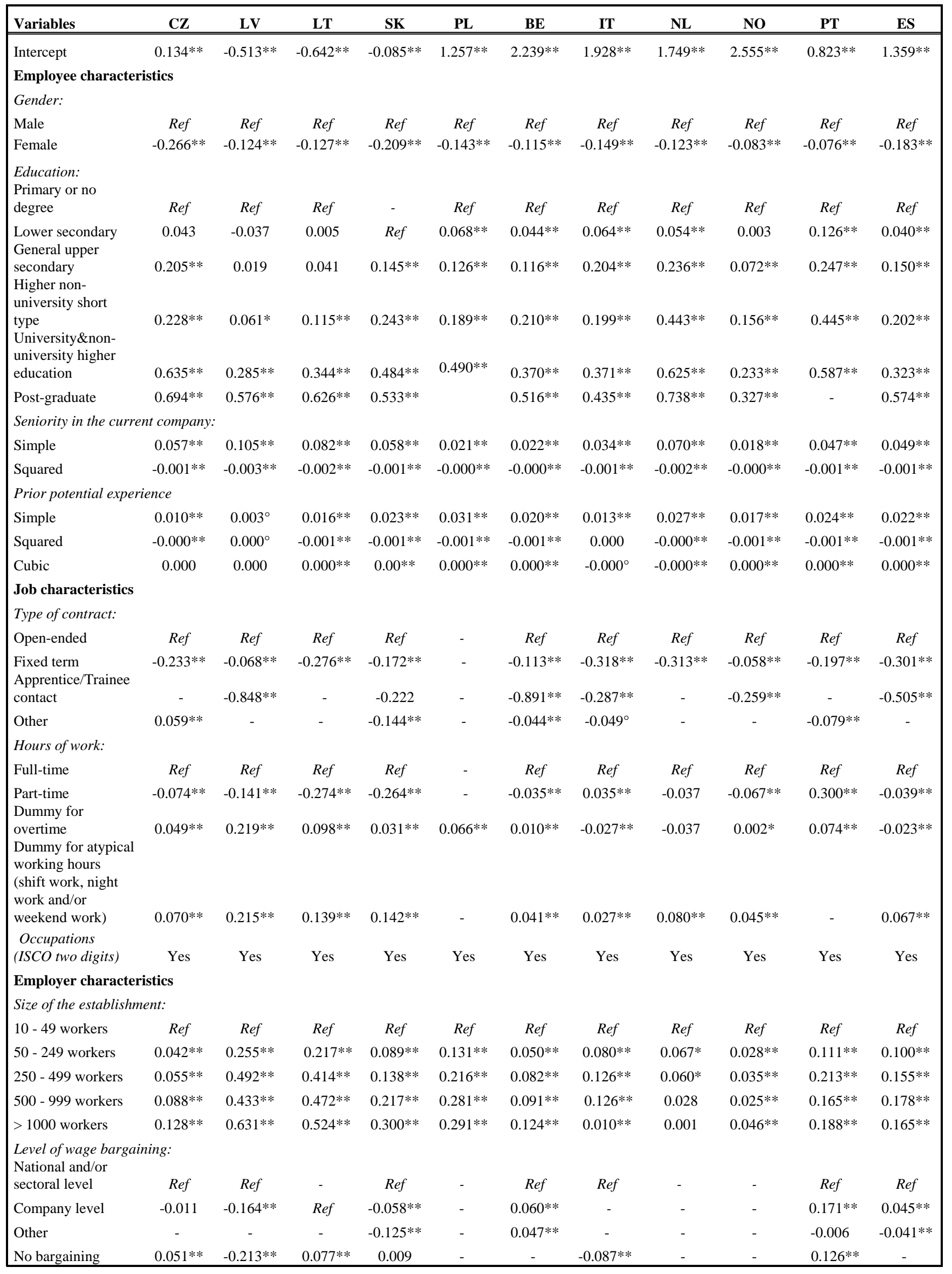




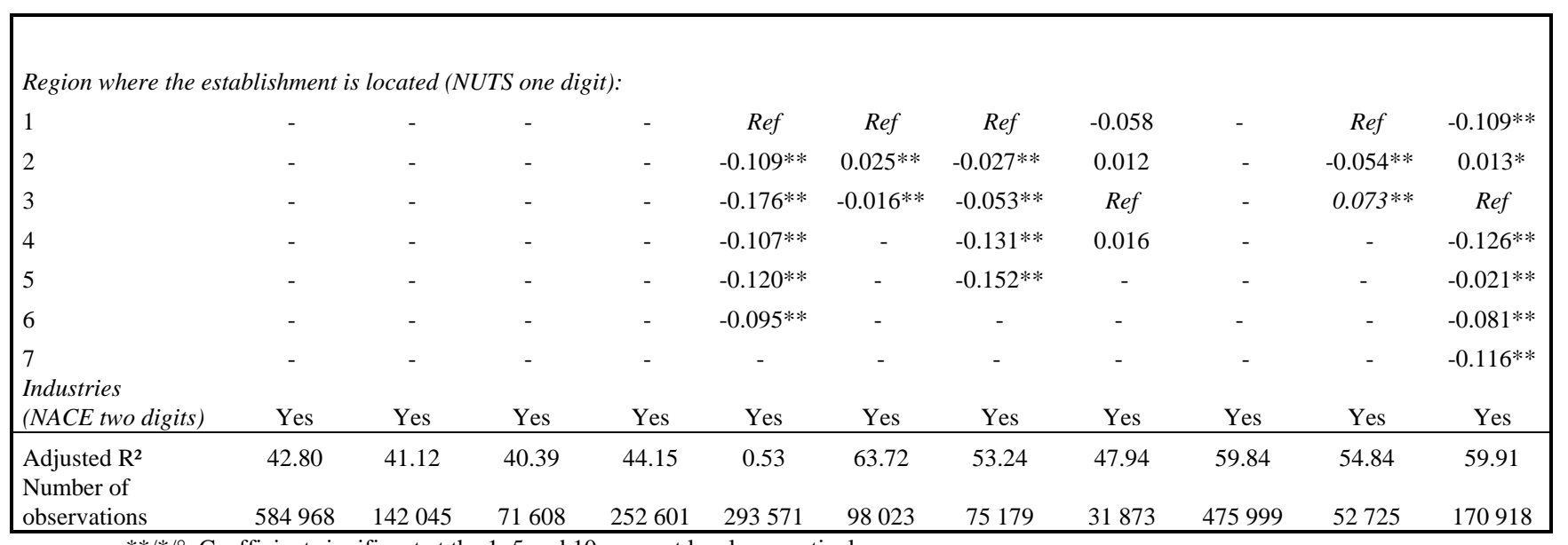

$* * / * /{ }^{\circ}$ : Coefficient significant at the 1,5 and 10 per cent level, respectively.

In all countries (except Italy) we also observe a concave relationship between the gross hourly wage and the general potential experience of a worker on the labour market. Initially, the return on an additional year of experience stands at between (slightly more than) 0 and 3\%, depending on the country under investigation. However, it decreases progressively and becomes negative after between 11 years of experience in Latvia and 29 years of experience in Norway. The hypothesis of a bell-shaped relationship between wages and experience rests upon the idea that the investment in human capital (specific training and accumulation by work) diminishes over time and that the stock of human capital suffers from some degree of obsolescence. The growing share of the relationship between wages and experience is explained essentially by the evolution of individual productivity and partly by scale increases.

The relationship between wages and seniority in the company is also in the form of a bell. However, the return on seniority is significantly higher and decreases markedly less quickly than that on experience. Initially, the return on an additional year of experience stands at between 2\% (in Norway and Belgium) and 11\% (in Latvia). Moreover, the return on an additional year of seniority becomes negative only after around 20 years of seniority in Latvia and 30 years of seniority in Norway. This difference (with respect to the return on general experience) can be explained through the almost automatic increase in wages as a function of years of seniority (in several European countries) and through the progression in the earnings classification (that is, promotion by seniority). It also illustrates the fact that companies offer more rewards for the human capital specific to their working environment. Finally, these results support the 'turnover' version of the efficiency wage theory (Stiglitz, 1974), according to which companies grant a bonus to workers who are faithful to them.

The dummy variables related to gender suggest that, all other things being equal, women are paid wages that are significantly lower than those of men in all countries. The gender wage gap fluctuates between $7.7 \%$ in Portugal and $23.7 \%$ in the Czech Republic. However, we cannot conclude that gender wage gaps are systematically bigger in Eastern European countries. Indeed, although Slovakia records the second largest gender wage gap (18.9\%), Latvia, Lithuania and Poland occupy an intermediate position among European countries. The gender wage penalty in these countries (around $12 \%-14 \%)$ is smaller than that in Italy and Spain, but bigger than in Portugal and Norway. 
Regarding job characteristics, we observe a wage penalty against workers with a fixedterm employment contract in all countries. This wage penalty varies between $5.8 \%$ in Norway and $27.4 \%$ in Italy. It is quite high in Lithuania and the Czech Republic (respectively $24.4 \%$ and $20.5 \%$ ), intermediate in Slovakia (15.6\%) and relatively small in Latvia (6.8\%). The existence of a wage penalty against workers with a fixed-term employment contract is compatible with the proposal put forward by Harris and Holmström (1982). According to this proposal, employers levy an amount on the wages of newcomers in order to pay for their uncertainty as to their productive ability. However, the reason why this wage penalty differs so much across European countries remains unclear. Table 2 reveals, in addition, the existence of a part-time wage gap in all countries (except Italy, the Netherlands and Portugal). This gap is systematically bigger in Eastern than in Western European countries. Indeed, it fluctuates between $6.8 \%$ and $-23.7 \%$ in the former countries and between $-6.8 \%$ and $+4.1 \%$ in the latter.

As regards employer characteristics, we observe that establishment size exercises a positive influence upon wages in all countries, but on a variable scale. Results show, for instance, that the wage differential between an establishment with between 10 and 49 workers and an establishment with between 250 and 499 workers varies from $6.2 \%$ in the Czech Republic to 63.2\% in Latvia. We also find a large establishment-size wage premium in Lithuania, while it appears to be more moderate in Slovakia. Finally, results for Western European countries (except Italy) indicate that workers covered by a company collective agreement earn between 5.1\% (in Spain) and 18.5\% (in Portugal) more than those whose wages are solely covered by a national and/or sectoral collective agreement. Results for Eastern European countries, although not directly comparable, go generally in the opposite direction.

\section{Inter-industry wage differentials}

Table 3 reports gross inter-industry wage differentials. These wage differentials have been obtained on the basis of a wage equation, using as dependent variable the (log of) individual gross hourly wages including annual bonuses and as independent variable only sectoral dummies (at the NACE two-digit level). 
Table 3: Gross inter-industry wage differentials (i.e. estimated without control variables), in log points

\begin{tabular}{|c|c|c|c|c|c|c|c|c|c|c|c|}
\hline & $\mathbf{C Z}$ & $\mathbf{L V}$ & LT & SK & PL & $\mathbf{B E}$ & IT & NL & NO & PT & ES \\
\hline $\begin{array}{l}10 \text { Mining of coal and } \\
\text { lignite, extraction of peat }\end{array}$ & $0.449 * *$ & $0.218 * *$ & $0.141^{* *}$ & $0.333^{* *}$ & $-0.166^{*}$ & $-0.272 * *$ & $-0.103^{* *}$ & - & $0.190 * *$ & - & $0.595^{* *}$ \\
\hline $\begin{array}{l}11 \text { Extraction of crude } \\
\text { petroleum and natural gas }\end{array}$ & $0.328 * *$ & - & $1.293 * *$ & $0.576^{* *}$ & $0.636^{* *}$ & - & $0.477 * *$ & $0.792 * *$ & $0.546^{* *}$ & - & $0.835^{* *}$ \\
\hline $\begin{array}{l}12 \text { Mining of uranium and } \\
\text { thorium ores }\end{array}$ & - & - & - & - & - & - & - & - & - & $0.429 * *$ & - \\
\hline 13 Mining of metal ores & - & - & - & $-0.560 * *$ & $0.917 * *$ & - & - & - & $0.111^{* *}$ & 0.002 & 0.176 \\
\hline $\begin{array}{l}14 \text { Other mining and } \\
\text { quarrying }\end{array}$ & $0.347 * *$ & $0.450 * *$ & $0.205^{* *}$ & $0.102^{\circ}$ & $0.227 * *$ & $-0.083 * *$ & -0.027 & $0.494 * *$ & $0.059 * *$ & 0.034 & $0.047 * *$ \\
\hline $\begin{array}{l}15 \text { Food products and } \\
\text { beverages }\end{array}$ & $-0.112 * *$ & - & 0.012 & $-0.198 * *$ & $-0.111^{* *}$ & - & $0.021 *$ & $0.183^{* *}$ & $-0.098 * *$ & $-0.052 * *$ & $-0.048 * *$ \\
\hline 16 Tobacco products & $0.941^{* *}$ & - & $1.551^{* *}$ & $0.393^{* *}$ & $0.664 * *$ & $-0.050^{*}$ & $0.441^{\circ}$ & $0.452 * *$ & -0.006 & -0.05 & $0.658^{* *}$ \\
\hline 17 Textiles & $-0.216^{* *}$ & $0.217 * *$ & $0.089 * *$ & $-0.366 * *$ & $-0.173^{* *}$ & $-0.268 * *$ & $-0.075^{* *}$ & $0.117 * *$ & $-0.151 * *$ & $-0.181 * *$ & $-0.117 * *$ \\
\hline 18 Clothing & $-0.505^{* *}$ & $-0.143 * *$ & $-0.128 * *$ & $-0.333 * *$ & $-0.449 * *$ & $-0.183^{* *}$ & $-0.336 * *$ & -0.092 & $-0.228 * *$ & $-0.385 * *$ & $-0.387 * *$ \\
\hline 19 Leather & $-0.444 * *$ & $-0.437 * *$ & -0.02 & $-0.377 * *$ & $-0.34 * *$ & $-0.172 * *$ & $-0.262 * *$ & -0.033 & $-0.145^{* *}$ & $-0.333 * *$ & $-0.368 * *$ \\
\hline 20 Wood and cork & $-0.067 * *$ & $-0.147 * *$ & $-0.273^{* *}$ & $-0.214 * *$ & $-0.224 * *$ & $-0.248 * *$ & $-0.215 * *$ & 0.101 & $-0.122 * *$ & $-0.104 * *$ & $-0.189 * *$ \\
\hline 21 Paper & $0.090^{*}$ & $0.100 * *$ & $0.418^{* *}$ & $0.308^{* *}$ & $0.125^{* *}$ & 0.003 & $0.054^{* *}$ & $0.234^{* *}$ & $0.012 * *$ & $0.265^{* *}$ & $0.244^{* *}$ \\
\hline 22 Printing and publishing & 0.007 & - & $0.099 * *$ & 0.021 & $0.223^{* *}$ & $0.067 * *$ & $0.156^{* *}$ & $0.265^{* *}$ & $0.119 * *$ & $0.283^{* *}$ & $0.247^{* *}$ \\
\hline $\begin{array}{l}23 \text { Coke, refined petroleum } \\
\text { products and nuclear fuel }\end{array}$ & $0.431 * *$ & - & $1.401 * *$ & $0.595^{* *}$ & $0.873^{* *}$ & $0.338 * *$ & $0.374 * *$ & $0.755^{* *}$ & $0.458 * *$ & - & $0.950 * *$ \\
\hline $\begin{array}{l}24 \text { Chemical and chemical } \\
\text { products }\end{array}$ & $0.169 * *$ & $0.298 * *$ & $0.501^{* *}$ & $0.131^{* *}$ & $0.362 * *$ & $0.201 * *$ & $0.277 * *$ & $0.438 * *$ & $0.200 * *$ & $0.481 * *$ & $0.461^{* *}$ \\
\hline $\begin{array}{l}25 \text { Rubber and plastic } \\
\text { products }\end{array}$ & $0.070 * *$ & $-0.116^{* *}$ & 0.015 & $0.207 * *$ & $0.04 * *$ & $-0.047 * *$ & $-0.035 * *$ & $0.132^{\circ}$ & $-0.057 * *$ & -0.013 & $0.183^{* *}$ \\
\hline $\begin{array}{l}26 \text { Other non-metallic } \\
\text { mineral products }\end{array}$ & $0.100 * *$ & $0.191 * *$ & $0.196 * *$ & $-0.028^{\circ}$ & $0.07 * *$ & $-0.025 * *$ & 0.000 & $0.229 * *$ & -0.005 & $0.109 * *$ & $0.128 * *$ \\
\hline 27 Basic metals & $0.123^{* *}$ & $0.538^{* *}$ & $0.350 * *$ & $0.455^{* *}$ & $0.209 * *$ & $0.053^{* *}$ & $0.053^{* *}$ & $0.352 * *$ & $0.106 * *$ & $0.164 * *$ & $0.434 * *$ \\
\hline 28 Fabricated metal products & 0.002 & $0.027 *$ & $-0.073^{* *}$ & $-0.091 * *$ & $-0.01 *$ & $-0.109 * *$ & $-0.054 * *$ & 0.026 & $-0.025 * *$ & -0.018 & $0.062 * *$ \\
\hline $\begin{array}{l}29 \text { Machinery and } \\
\text { equipment }\end{array}$ & $0.045^{* *}$ & $0.142 * *$ & $0.266^{* *}$ & $-0.040 * *$ & $0.113^{* *}$ & $0.020^{*}$ & $0.051^{* *}$ & $0.293 * *$ & $0.056^{* *}$ & $0.143^{* *}$ & $0.212^{* *}$ \\
\hline $\begin{array}{l}30 \text { Office machinery and } \\
\text { computers }\end{array}$ & $-0.119 * *$ & $0.462^{* *}$ & $-0.290 * *$ & $-0.082 *$ & - & $-0.104 * *$ & 0.036 & $0.286 * *$ & $0.140 * *$ & - & $0.419 * *$ \\
\hline $\begin{array}{l}31 \text { Electrical machinery and } \\
\text { apparatus }\end{array}$ & $-0.076 * *$ & $0.322 * *$ & $0.355^{* *}$ & $-0.158 * *$ & $0.102 * *$ & 0.016 & 0.012 & $0.186^{* *}$ & $0.104 * *$ & $0.170^{* *}$ & $0.180 * *$ \\
\hline $\begin{array}{l}32 \text { Radio, television and } \\
\text { communication equipment }\end{array}$ & $-0.105^{* *}$ & $-0.146 * *$ & $0.365^{* *}$ & $-0.374 *$ & $0.327 * *$ & $0.198 * *$ & $0.110 * *$ & $0.334 * *$ & $0.158 * *$ & $0.316^{* *}$ & $0.210 * *$ \\
\hline $\begin{array}{l}33 \text { Medical, precision and } \\
\text { optical instruments, watches } \\
\text { and clocks }\end{array}$ & $-0.164 * *$ & $0.174 * *$ & $0.315^{* *}$ & $0.143^{* *}$ & $0.172 * *$ & $-0.065 * *$ & $0.062 * *$ & $0.172 * *$ & $0.195 * *$ & $0.186^{* *}$ & $0.324 * *$ \\
\hline $\begin{array}{l}34 \text { Motor vehicles, trailers } \\
\text { and semi-trailers }\end{array}$ & $0.223^{* *}$ & $0.078^{*}$ & 0.06 & $0.476^{* *}$ & $0.164^{* *}$ & $0.024^{* *}$ & $0.029 * *$ & $0.167 * *$ & -0.004 & $0.157^{* *}$ & $0.359 * *$ \\
\hline $\begin{array}{l}35 \text { Other transport } \\
\text { equipment }\end{array}$ & $0.103^{* *}$ & $0.331^{* *}$ & $0.565^{* *}$ & $0.159 * *$ & $0.202^{* *}$ & $0.026^{\circ}$ & -0.003 & $0.182 * *$ & $0.072 * *$ & $0.301^{* *}$ & $0.280 * *$ \\
\hline 36 Furniture, manufacturing & $-0.150 * *$ & -0.022 & $-0.074 * *$ & $-0.350 * *$ & $-0.176^{* *}$ & $-0.251^{* *}$ & $-0.225 * *$ & -0.065 & $-0.093 * *$ & $-0.234 * *$ & $-0.167 * *$ \\
\hline 37 Recycling & $-0.101^{* *}$ & $-0.214^{* *}$ & $-0.149 *$ & $-0.311^{* *}$ & $0.046+$ & $-0.288 * *$ & $-0.189 * *$ & -0.089 & -0.023 & -0.025 & 0.076 \\
\hline $\begin{array}{l}40 \text { Electricity, gas, steam } \\
\text { and hot water supply }\end{array}$ & $0.254^{* *}$ & $0.909 * *$ & $0.547^{* *}$ & $0.532 * *$ & $0.384 * *$ & $0.460 * *$ & $0.405^{* *}$ & $0.373^{* *}$ & $0.035^{* *}$ & $0.972 * *$ & $0.910^{* *}$ \\
\hline $\begin{array}{l}41 \text { Collection, purification } \\
\text { and distribution of water }\end{array}$ & $0.182 * *$ & - & $-0.131 * *$ & 0.025 & $0.275^{* *}$ & - & $0.250 * *$ & $0.482 * *$ & - & $0.550 * *$ & $0.224 * *$ \\
\hline
\end{tabular}




\begin{tabular}{|c|c|c|c|c|c|c|c|c|c|c|c|}
\hline & $\mathbf{C Z}$ & LV & $\mathbf{L T}$ & SK & PL & $\mathbf{B E}$ & IT & NL & NO & PT & ES \\
\hline 45 Construction & $-0.032 * *$ & $-0.117 * *$ & $-0.181 * *$ & $-0.267 * *$ & $-0.056^{* *}$ & $-0.166^{* *}$ & $-0.133 * *$ & $0.102^{* *}$ & $0.011^{* *}$ & $-0.086 * *$ & $-0.178^{* *}$ \\
\hline $\begin{array}{l}50 \text { Sale, maintenance and } \\
\text { repair of motor vehicles } \\
\text { and motorcycles }\end{array}$ & -0.041 & $-0.087 * *$ & - & 0.009 & 0.008 & -0.007 & $-0.031 * *$ & -0.047 & $-0.074 * *$ & $0.077 * *$ & $0.027^{\circ}$ \\
\hline 51 Wholesale trade & $0.060 *$ & -0.001 & $0.166^{* *}$ & -0.018 & $0.031^{* *}$ & $0.060 * *$ & $0.078^{* *}$ & $0.080^{*}$ & $0.094 * *$ & $0.149 * *$ & $0.043^{* *}$ \\
\hline 52 Retail trade & $-0.339 * *$ & $-0.309 * *$ & $-0.197 * *$ & $-0.250 * *$ & $-0.266^{* *}$ & $-0.209 * *$ & $-0.075 * *$ & $-0.427 * *$ & $-0.277 * *$ & $-0.266 * *$ & $-0.207 * *$ \\
\hline 55 Hotels and restaurants & $-0.377 * *$ & $-0.342 * *$ & $-0.431^{* *}$ & $-0.473 * *$ & $-0.226 * *$ & $-0.473 * *$ & $-0.265^{* *}$ & $-0.394 * *$ & $-0.276^{* *}$ & $-0.329 * *$ & $-0.319 * *$ \\
\hline $\begin{array}{l}60 \text { Land transport; transport } \\
\text { via pipelines }\end{array}$ & $0.028^{* *}$ & $-0.250 * *$ & $-0.466 * *$ & $0.110^{* *}$ & $-0.022 * *$ & $-0.345^{* *}$ & -0.006 & -0.121 & $-0.101 * *$ & $0.065 * *$ & $-0.040 * *$ \\
\hline 61 Water transport & & $0.787^{* *}$ & $0.713^{* *}$ & - & $0.909 * *$ & -0.039 & $0.266^{* *}$ & $0.289 * *$ & $0.087 * *$ & $0.449 * *$ & - \\
\hline 62 Air transport & $1.272 * *$ & $0.270 * *$ & 0.11 & $0.352 * *$ & $0.72 * *$ & $0.096 *$ & $0.352 * *$ & $0.355^{* *}$ & $0.250^{* *}$ & $0.618 * *$ & $0.578 * *$ \\
\hline 63 Transport activities & $0.130 * *$ & $0.414^{* *}$ & $0.242 * *$ & $-0.070^{*}$ & $0.179 * *$ & $-0.095 * *$ & $0.037^{*}$ & 0.087 & $-0.026 * *$ & $0.463^{* *}$ & $0.033^{*}$ \\
\hline $\begin{array}{l}64 \text { Post and } \\
\text { telecommunications }\end{array}$ & $0.779 * *$ & $1.247 * *$ & $0.815^{* *}$ & $0.406 * *$ & $0.8^{* *}$ & $0.155^{* *}$ & $-0.282 *$ & $0.082^{* *}$ & $0.166^{* *}$ & $0.942 * *$ & $0.689 * *$ \\
\hline 65 Financial intermediation & $0.582 * *$ & $1.044^{* *}$ & $0.892^{* *}$ & $0.643^{* *}$ & $0.582 * *$ & $0.316^{* *}$ & $0.650 * *$ & $0.485^{* *}$ & $0.156^{* *}$ & $0.898^{* *}$ & $0.867 * *$ \\
\hline $\begin{array}{l}66 \text { Insurance and pension } \\
\text { funding }\end{array}$ & $0.467 * *$ & $0.648^{* *}$ & $0.439 * *$ & $0.233^{* *}$ & $0.614^{* *}$ & $0.260 * *$ & $0.477^{* *}$ & $0.417^{* *}$ & $0.188^{* *}$ & $0.955^{* *}$ & $0.512 * *$ \\
\hline $\begin{array}{l}67 \text { Activities auxiliary to } \\
\text { financial intermediation }\end{array}$ & $0.667^{* *}$ & 0.072 & $-0.120^{\circ}$ & $0.534^{* *}$ & $0.329 * *$ & $0.254^{* *}$ & $0.200^{* *}$ & $0.286^{* *}$ & $0.427^{* *}$ & $0.796^{* *}$ & $0.464^{* *}$ \\
\hline 70 Real estate activities & $0.102 * *$ & $-0.107^{* *}$ & -0.026 & $0.119 * *$ & $0.154^{* *}$ & $-0.116^{* *}$ & 0.043 & $0.413^{* *}$ & $0.061^{* *}$ & $0.119^{\circ}$ & 0.021 \\
\hline 71 Renting of machinery & $0.643^{* *}$ & $0.734^{* *}$ & -0.023 & $0.251^{* *}$ & $0.465^{* *}$ & -0.008 & $0.086^{*}$ & -0.108 & $-0.073 * *$ & $0.157 * *$ & $-0.215^{* *}$ \\
\hline $\begin{array}{l}72 \text { Computer and related } \\
\text { activities }\end{array}$ & $0.238^{*}$ & $0.827^{* *}$ & $0.395^{* *}$ & $0.586^{* *}$ & $0.69 * *$ & $0.202 * *$ & $0.235^{* *}$ & $0.393^{* *}$ & $0.356^{* *}$ & $0.751^{* *}$ & $0.217^{* *}$ \\
\hline $\begin{array}{l}73 \text { Research and } \\
\text { development }\end{array}$ & $0.151^{* *}$ & $0.158^{\circ}$ & -0.026 & $0.358^{* *}$ & $0.482 * *$ & $0.171^{* *}$ & $0.176^{* *}$ & $0.475^{* *}$ & $0.257 * *$ & $0.549 * *$ & $0.443^{* *}$ \\
\hline $\begin{array}{l}74 \text { Other businesses } \\
\text { activities }\end{array}$ & $-0.160 * *$ & $0.069 * *$ & $-0.089 * *$ & $-0.155^{* *}$ & $-0.164 * *$ & $-0.111 * *$ & $-0.150 * *$ & $-0.270 * *$ & $0.044 * *$ & $0.177^{* *}$ & $-0.220 * *$ \\
\hline
\end{tabular}

Note: $* * / * /{ }^{\circ}$ : Coefficient significant at the 1,5 and 10 per cent level, respectively.

Results show, for all countries, the existence of substantial wage differentials between workers employed in different sectors. These are significant at the $1 \%$ level, both in individual terms (with a few exceptions) and globally. Moreover, we find that the hierarchy of sectors in terms of wages is quite similar across European countries (see Appendix 2). ${ }^{5}$ Among the best paid sectors we find the extraction of crude petroleum and natural gas industry, the coking, refining and nuclear industry, the chemical industry, the production and distribution of electricity, gas, steam and hot water, the air transport sector, the financial sector, and computer activities. Notice that the size of the wage differentials associated with these sectors fluctuates substantially. For instance, we find that the average worker in the extraction of crude petroleum and natural gas industry earns between $50.8 \%{ }^{6}$ (in the Czech Republic) and 315.6\% (in Lithuania) more

5 Spearman correlation coefficients between gross inter-industry wage differentials computed for different countries are significant at the $1 \%$ level. Their value fluctuates between $46 \%$ and $86 \%$.

6 In order to get the difference in percentage between the wage (in euros) of the average worker in sector $m$ and the employment-share weighted mean wage (in euros) in the economy, the following expressions have been computed:

$$
v_{m}=\left[\left(\exp \left(\hat{\psi}_{m}\right)-1\right)-\sum_{m=1}^{M} \bar{p}_{m}\left(\exp \left(\hat{\psi}_{m}\right)-1\right)\right],
$$


than the average worker in the whole economy. In the coking, refining and nuclear industry, these percentages vary between $46.3 \%$ in Italy and $365.8 \%$ in Lithuania. At the bottom of the wage distribution, we find traditional sectors, including the clothing and fur industry, the leather and footwear industry, woodwork and the manufacture of articles in wood, cork and esparto, retail trade, and hotels and restaurants. Again, substantial differences are observed in the wage differentials associated with these sectors. For instance, workers in the clothing and fur industry earn between almost 20\% (in the Netherlands) and 60\% (in the Czech Republic) less than the average worker in the economy. In the retail trade, these percentages vary between $-10.4 \%$ in Italy and $59.6 \%$ in the Netherlands. Finally, the average worker in the hotels and restaurants sector is found to earn between $27.8 \%$ (in Italy) and $49.3 \%$ (in Lithuania) less than the average worker in the whole economy.

\section{Table 4: Net inter-industry wage differentials (i.e. controlling for employee, job and employer characteristics, except the level of wage bargaining), in log points}

\begin{tabular}{|c|c|c|c|c|c|c|c|c|c|c|c|}
\hline & $\mathbf{C Z}$ & $\mathbf{L V}$ & $\mathbf{L T}$ & SK & PL & BE & IT & NL & NO & PT & ES \\
\hline $\begin{array}{l}10 \text { Mining of coal and lignite, } \\
\text { extraction of peat }\end{array}$ & $0.283^{* *}$ & $0.403 * *$ & $0.180^{* *}$ & -0.015 & -0.085 & $-0.184 * *$ & $-0.228 * *$ & - & $0.122 * *$ & - & $0.428 * *$ \\
\hline $\begin{array}{l}11 \text { Extraction of crude petroleum } \\
\text { and natural gas }\end{array}$ & $0.037^{\circ}$ & - & $1.115^{* *}$ & $0.351^{* *}$ & $0.495 * *$ & - & $0.260^{\circ}$ & $0.358 * *$ & $0.368 * *$ & - & $0.188^{* *}$ \\
\hline $\begin{array}{l}12 \text { Mining of uranium and } \\
\text { thorium ores }\end{array}$ & - & - & - & - & - & - & - & - & - & $-0.112 *$ & - \\
\hline 13 Mining of metal ores & - & - & - & $-0.645^{* *}$ & $0.593^{* *}$ & - & - & - & $0.078^{* *}$ & 0.019 & $-0.246^{*}$ \\
\hline 14 Other mining and quarrying & $0.256^{* *}$ & $0.400 * *$ & $0.270^{* *}$ & $0.221^{* *}$ & $0.143 * *$ & 0.005 & $0.034^{*}$ & 0.107 & $0.072 * *$ & $0.062 *$ & $0.129 * *$ \\
\hline 15 Food products and beverages & $-0.028 * *$ & & $-0.053 * *$ & $-0.134 * *$ & $-0.057 * *$ & & $0.060 * *$ & $0.071^{*}$ & $-0.025 * *$ & $-0.045^{* *}$ & $-0.066 * *$ \\
\hline 16 Tobacco products & $0.555^{* *}$ & & $0.947 * *$ & $0.371^{* *}$ & $0.334 * *$ & $0.040^{* *}$ & 0.24 & $0.071^{\circ}$ & $-0.027 * *$ & 0.045 & $0.253^{* *}$ \\
\hline 17 Textiles & $-0.108 * *$ & $-0.103 * *$ & $-0.111^{* *}$ & $-0.204 * *$ & $-0.12^{* *}$ & $-0.127 * *$ & $-0.027^{*}$ & $-0.122 *$ & $-0.080 * *$ & $-0.146 * *$ & $-0.136 * *$ \\
\hline 18 Clothing & $-0.215^{* *}$ & $-0.073 * *$ & $-0.089 * *$ & $-0.138 * *$ & $-0.221 * *$ & $-0.086 * *$ & $-0.111 * *$ & $-0.175^{\circ}$ & $-0.132 * *$ & $-0.182 * *$ & $-0.137 * *$ \\
\hline 19 Leather & $-0.292 * *$ & $-0.213^{* *}$ & $-0.128 * *$ & $-0.152 * *$ & $-0.125 * *$ & $-0.114 * *$ & $-0.120 * *$ & -0.132 & $-0.077 * *$ & $-0.113 * *$ & $-0.160 * *$ \\
\hline 20 Wood and cork & -0.009 & $-0.080 * *$ & $-0.124 * *$ & $-0.070 *$ & $-0.126 * *$ & $-0.132 * *$ & $-0.123 * *$ & $-0.108 *$ & $-0.100 * *$ & -0.016 & $-0.112 * *$ \\
\hline 21 Paper & $0.117 * *$ & $0.075 * *$ & $0.255^{* *}$ & $0.169^{* *}$ & $0.072 * *$ & $0.050 * *$ & $0.032 * *$ & 0.024 & $-0.032 * *$ & $0.099^{* *}$ & $0.032 * *$ \\
\hline 22 Printing and publishing & $0.043^{\circ}$ & - & 0.034 & $0.033^{\circ}$ & $0.113^{* *}$ & $0.044 * *$ & $0.117 * *$ & 0.044 & $0.046^{* *}$ & $0.118^{* *}$ & $0.054 * *$ \\
\hline $\begin{array}{l}23 \text { Coke, refined petroleum } \\
\text { products and nuclear fuel }\end{array}$ & $0.228 * *$ & - & $0.756^{* *}$ & $0.500 * *$ & $0.363 * *$ & $0.171^{* *}$ & $0.230 * *$ & $0.227 * *$ & $0.132^{* *}$ & - & $0.321^{* *}$ \\
\hline $\begin{array}{l}24 \text { Chemical and chemical } \\
\text { products }\end{array}$ & $0.050^{* *}$ & 0.017 & $0.163^{* *}$ & $-0.108 * *$ & $0.152 * *$ & $0.107^{* *}$ & $0.121^{* *}$ & $0.074^{*}$ & $0.062^{* *}$ & $0.218^{* *}$ & $0.132 * *$ \\
\hline 25 Rubber and plastic products & $0.138 * *$ & $-0.053 * *$ & $0.094 * *$ & $0.127^{* *}$ & $0.059 * *$ & $-0.036 * *$ & $-0.018^{*}$ & -0.066 & $-0.045^{* *}$ & -0.025 & $0.064^{* *}$ \\
\hline $\begin{array}{l}26 \text { Other non-metallic mineral } \\
\text { products }\end{array}$ & $0.105^{* *}$ & $0.126 * *$ & $0.109 * *$ & $-0.062 * *$ & $0.042 * *$ & 0.008 & $0.023^{* *}$ & -0.048 & $-0.016^{* *}$ & $0.060^{* *}$ & $0.063 * *$ \\
\hline 27 Basic metals & $0.016^{\circ}$ & $-0.150 * *$ & $-0.130 * *$ & $0.234 * *$ & $0.04 * *$ & -0.008 & $0.032 * *$ & 0.051 & $0.049 * *$ & 0.001 & $0.092^{* *}$ \\
\hline 28 Fabricated metal products & -0.004 & 0.013 & $-0.044^{*}$ & $-0.075^{* *}$ & $-0.051^{* *}$ & $-0.041^{* *}$ & 0.01 & -0.001 & $-0.026 * *$ & 0.008 & $0.029 * *$ \\
\hline 29 Machinery and equipment & $-0.069 * *$ & $-0.165 * *$ & $-0.063 * *$ & $-0.062 * *$ & 0.001 & -0.004 & $0.038 * *$ & 0.007 & $0.012 * *$ & $0.047 * *$ & $0.042 * *$ \\
\hline $\begin{array}{l}30 \text { Office machinery and } \\
\text { computers }\end{array}$ & $-0.167 * *$ & $0.542 * *$ & $-0.227 * *$ & $0.101^{* *}$ & - & $-0.118^{* *}$ & -0.022 & $-0.087 *$ & -0.011 & - & -0.064 \\
\hline
\end{tabular}

where $\bar{p}_{m}$ (for $m=1, \ldots, M+1$ ) is the sectoral employment share. This transformation is necessary because the estimated wage equation has a semi-logarithmic form (for a discussion see Reilly and Zanchi, 2003). See Appendix 1 for results expressed in percentage terms. 


\begin{tabular}{|c|c|c|c|c|c|c|c|c|c|c|c|}
\hline & $\mathbf{C Z}$ & $\mathbf{L V}$ & LT & SK & PL & BE & IT & NL & NO & PT & ES \\
\hline $\begin{array}{l}31 \text { Electrical machinery and } \\
\text { apparatus }\end{array}$ & $-0.025 * *$ & 0.022 & $0.092 * *$ & $-0.077^{* *}$ & $-0.02 * *$ & $-0.023 * *$ & -0.011 & -0.09 & $0.036 * *$ & $0.045 * *$ & $0.017^{*}$ \\
\hline $\begin{array}{l}32 \text { Radio, television and } \\
\text { communication equipment }\end{array}$ & -0.011 & $-0.094 * *$ & $-0.060 *$ & $-0.395^{* *}$ & $0.142 * *$ & $0.079 * *$ & -0.009 & 0.02 & $0.025^{* *}$ & $0.048^{\circ}$ & 0.016 \\
\hline $\begin{array}{l}33 \text { Medical, precision and optical } \\
\text { instruments, watches and clocks }\end{array}$ & $-0.133^{* *}$ & $-0.069 *$ & $0.147^{* *}$ & 0.024 & $0.048 * *$ & $-0.038 * *$ & -0.001 & $-0.125 *$ & $0.054 * *$ & -0.124 & -0.018 \\
\hline $\begin{array}{l}34 \text { Motor vehicles, trailers and } \\
\text { semi-trailers }\end{array}$ & $0.191^{* *}$ & 0.043 & 0.002 & $0.478 * *$ & $0.028 * *$ & $0.010^{\circ}$ & -0.002 & -0.014 & $-0.032 * *$ & $0.084^{* *}$ & $0.054 * *$ \\
\hline 35 Other transport equipment & $-0.044 * *$ & 0.02 & $0.219 * *$ & 0.004 & $0.027 * *$ & $-0.061 * *$ & $-0.061^{* *}$ & -0.016 & $0.016^{* *}$ & $0.108^{* *}$ & $0.044 * *$ \\
\hline 36 Furniture, manufacturing & $-0.070 * *$ & 0.001 & $-0.094 * *$ & $-0.132 * *$ & $-0.079 * *$ & $-0.153 * *$ & $-0.116 * *$ & -0.238 & $-0.043 * *$ & $-0.111 * *$ & $-0.092 * *$ \\
\hline 37 Recycling & $-0.118 * *$ & -0.013 & -0.008 & $-0.303^{* *}$ & $0.061 * *$ & $-0.081 * *$ & $-0.056 * *$ & $-0.234 *$ & $0.027^{*}$ & $0.128^{*}$ & $0.107 * *$ \\
\hline $\begin{array}{l}40 \text { Electricity, gas, steam and hot } \\
\text { water supply }\end{array}$ & $0.110^{* *}$ & $0.276^{* *}$ & $0.247 * *$ & $0.226^{* *}$ & $0.221^{* *}$ & $0.292 * *$ & $0.170^{* *}$ & $0.099 * *$ & $-0.065^{* *}$ & $0.387 * *$ & $0.295^{* *}$ \\
\hline $\begin{array}{l}41 \text { Collection, purification and } \\
\text { distribution of water }\end{array}$ & $0.030^{* *}$ & - & $-0.106^{* *}$ & $-0.052 *$ & $0.166 * *$ & - & $0.136^{* *}$ & $0.140^{* *}$ & - & $0.250^{* *}$ & $0.049 * *$ \\
\hline 45 Construction & $-0.041 * *$ & $-0.079 * *$ & -0.018 & $-0.169 * *$ & $-0.048 * *$ & $-0.051^{* *}$ & $-0.022^{\circ}$ & $0.069^{*}$ & $0.039 * *$ & $-0.027^{*}$ & $0.071^{* *}$ \\
\hline $\begin{array}{l}50 \text { Sale, maintenance and repair } \\
\text { of motor vehicles and } \\
\text { motorcycles }\end{array}$ & -0.047 & 0.002 & - & $0.159 * *$ & $0.063^{* *}$ & 0.009 & $0.016^{\circ}$ & 0.003 & $-0.043 * *$ & $0.044^{* *}$ & $-0.024 *$ \\
\hline 51 Wholesale trade & $0.079 * *$ & $0.072 * *$ & $0.162 * *$ & $0.066^{*}$ & $0.026 * *$ & $0.010^{*}$ & $0.042 * *$ & 0.025 & $0.006 * *$ & $0.050 * *$ & -0.007 \\
\hline 52 Retail trade & $-0.203^{* *}$ & $-0.164 * *$ & $-0.062^{* *}$ & -0.022 & $-0.161^{* *}$ & $-0.052^{* *}$ & 0.009 & -0.043 & $-0.113^{* *}$ & $-0.180 * *$ & $-0.100 * *$ \\
\hline 55 Hotels and restaurants & 0.019 & -0.021 & $-0.091^{* *}$ & $-0.081^{* *}$ & $0.056 * *$ & $-0.220 * *$ & $-0.140 * *$ & 0.001 & $-0.031^{* *}$ & $-0.124 * *$ & $-0.074 * *$ \\
\hline $\begin{array}{l}60 \text { Land transport; transport via } \\
\text { pipelines }\end{array}$ & 0.005 & $-0.148 * *$ & $-0.249 * *$ & $-0.090 * *$ & $-0.019 * *$ & $-0.144^{* *}$ & $0.026^{*}$ & -0.109 & $-0.024 * *$ & 0.011 & 0.01 \\
\hline 61 Water transport & - & $0.718^{* *}$ & $0.153^{* *}$ & - & $0.715^{* *}$ & -0.026 & $0.181^{* *}$ & -0.037 & $0.012 * *$ & $0.224 * *$ & - \\
\hline 62 Air transport & $1.370^{* *}$ & $0.154 * *$ & 0.021 & $0.315^{* *}$ & $0.482 * *$ & $0.098 * *$ & $0.350 * *$ & $0.199 * *$ & $0.183^{* *}$ & $0.243 * *$ & $0.201 * *$ \\
\hline 63 Transport activities & $0.210^{* *}$ & $0.274 * *$ & $0.189 * *$ & 0.042 & $0.138 * *$ & $-0.017^{*}$ & $0.027^{*}$ & $0.090^{\circ}$ & $-0.007 *$ & $0.316^{* *}$ & 0.015 \\
\hline 64 Post and telecommunications & $0.531^{* *}$ & $0.947 * *$ & $0.466 * *$ & $0.093 * *$ & $0.347 * *$ & $0.037 * *$ & $-0.432 * *$ & $0.095 * *$ & $0.080 * *$ & $0.500 * *$ & $0.149 * *$ \\
\hline 65 Financial intermediation & $0.189 * *$ & $0.508 * *$ & $0.447 * *$ & $0.393 * *$ & $0.303^{* *}$ & $0.072 * *$ & $0.329 * *$ & $0.267 * *$ & $-0.052 * *$ & $0.440 * *$ & $0.291^{* *}$ \\
\hline $\begin{array}{l}66 \text { Insurance and pension } \\
\text { funding }\end{array}$ & $0.231^{* *}$ & $0.062^{\circ}$ & $0.307^{* *}$ & $0.094^{* *}$ & $0.261^{* *}$ & $0.087^{* *}$ & $0.197 * *$ & $0.158^{* *}$ & $-0.053 * *$ & $0.355^{* *}$ & $0.040^{* *}$ \\
\hline $\begin{array}{l}67 \text { Activities auxiliary to } \\
\text { financial intermediation }\end{array}$ & $0.494^{* *}$ & 0.122 & $0.148^{*}$ & $0.349^{* *}$ & $0.12^{* *}$ & $0.026^{*}$ & $0.095^{* *}$ & $0.342^{* *}$ & $0.238 * *$ & $0.411^{* *}$ & $0.135^{* *}$ \\
\hline 70 Real estate activities & $0.028 *$ & $0.084 * *$ & $0.161^{* *}$ & $0.086 * *$ & $0.19 * *$ & -0.018 & 0.018 & $0.149 * *$ & $0.028 * *$ & $0.079^{\circ}$ & 0.036 \\
\hline 71 Renting of machinery & $0.531^{* *}$ & $0.711^{* *}$ & 0.118 & $0.225 * *$ & $0.254 * *$ & $0.026^{*}$ & $0.082^{* *}$ & -0.086 & -0.001 & $0.077^{* *}$ & -0.046 \\
\hline $\begin{array}{l}72 \text { Computer and related } \\
\text { activities }\end{array}$ & -0.049 & $0.546^{* *}$ & $0.257^{* *}$ & $0.332 * *$ & $0.302^{* *}$ & -0.009 & $0.096^{* *}$ & 0.072 & $0.132 * *$ & $0.227^{* *}$ & $-0.048 * *$ \\
\hline 73 Research and development & $-0.107 * *$ & -0.089 & -0.03 & $-0.102 * *$ & $0.148 * *$ & $-0.029 *$ & 0.023 & $0.101^{*}$ & $-0.073 * *$ & $0.290 * *$ & $-0.093 *$ \\
\hline 74 Other businesses activities & $-0.061^{* *}$ & $0.182 * *$ & 0.002 & -0.01 & $-0.026 * *$ & $-0.025 * *$ & $-0.131 * *$ & $-0.148 * *$ & $0.023^{* *}$ & $0.153 * *$ & $-0.102 * *$ \\
\hline
\end{tabular}

$* * / * /{ }^{\circ}$ : Coefficient significant at the 1,5 and 10 per cent level, respectively.

Table 4 reports the net inter-industry wage differentials, that is, stripped of employee, job and employer characteristics (as described in equation (1)). ${ }^{7}$ Results show that substantial earnings differences across sectors persist in all countries after controlling for a large range of potential composition effects. The vast majority of these differentials are still significant at the $1 \%$ level. Also noteworthy is that the hierarchy of

\footnotetext{
We do not control for the level of wage bargaining as this variable is not available for Norway and the
} Netherlands. Results in percentage terms are reported in Appendix 3. 
sectors in terms of wages remains almost unchanged in all countries. ${ }^{8}$ Among highwage sectors, we still find the energy (coke, petroleum, gas, electricity and nuclear power), chemical, financial and computer industries. Moreover, it is still in the traditional sectors (wood and cork industry, textile, clothing and leather industry, hotels and restaurants, and retailing) that wages are lowest. ${ }^{9}$ However, the size of the interindustry wage differentials is substantially reduced after the introduction of control variables for employee, job and employer characteristics. Notice, for instance, that the wage premium for someone employed in the extraction of crude petroleum and natural gas industry drops from 50.8\% to 3.5\% in the Czech Republic and from 315.6\% to $216.4 \%$ in Lithuania. In the coking, refining and nuclear industry, the average worker now earns $15.5 \%$ in Norway and $118.6 \%$ in Lithuania more than the average worker in the whole economy, ceteris paribus. The wage premium in this sector is thus approximately divided by 3 in Norway and Lithuania. At the other side of the wage distribution, we find, for example, that the wage penalty in the hotels and restaurants sector decreases from $27.8 \%$ to $13.7 \%$ in Italy and from $49.3 \%$ to $10.8 \%$ in Lithuania.

Table 5: Dispersion (WASD) of inter-industry wage differentials

\begin{tabular}{|c|c|c|c|c|c|c|c|c|c|c|c|}
\hline Model: & $\mathbf{C Z}$ & $\mathbf{L V}$ & $\mathbf{L T}$ & SK & PL & BE & IT & NL & NO & PT & ES \\
\hline 1. Including only sectoral dummies: & 0.219 & 0.328 & 0.298 & 0.287 & 0.252 & 0.184 & 0.209 & 0.281 & 0.169 & 0.279 & 0.296 \\
\hline $\begin{array}{l}\text { 2. Controlling for employee } \\
\text { characteristics: }\end{array}$ & 0.145 & 0.243 & 0.229 & 0.182 & 0.175 & 0.111 & 0.133 & 0.132 & 0.103 & 0.185 & 0.132 \\
\hline $\begin{array}{l}\text { 3. Controlling for employee and job } \\
\text { characteristics: }\end{array}$ & 0.128 & 0.209 & 0.203 & 0.194 & 0.141 & 0.085 & 0.125 & 0.102 & 0.075 & 0.150 & 0.112 \\
\hline $\begin{array}{l}\text { 4. Controlling for employee, job and } \\
\text { employer characteristics, } \\
\text { excluding the level of wage } \\
\text { bargaining: }\end{array}$ & 0.123 & 0.180 & 0.162 & 0.161 & 0.127 & 0.076 & 0.121 & 0.103 & 0.074 & 0.137 & 0.101 \\
\hline
\end{tabular}

What about the dispersion of inter-industry wage differentials? Table 5 shows that the weighted adjusted standard deviation (WASD) of the inter-industry wage differentials is substantially reduced when controlling for employee, job and employer characteristics. Indeed, the WASD drops by between $42 \%$ (in Italy) and 66\% (in Spain) when controlling for composition effects. Moreover, we find that the dispersion of interindustry wage differentials fluctuates considerably between countries. It varies from 0.074 in Norway to 0.180 in Latvia. Results for Western European countries (except

8 Spearman correlation coefficients between net inter-industry wage differentials recorded for different countries are generally significant at the $1 \%$ level. Their value varies between $27 \%$ and $68 \%$. See Appendix 4.

9 These results could be altered by the inclusion of firm and worker fixed effects. Since a longitudinal data set including the same quality of information is not available at the European level, we cannot use panel data techniques to control for these effects. But we note that several studies confirm the existence of industry differentials even when individual and firm effects are controlled for. Another option for investigating firm effects relies on the inclusion of dummy variables for each firm in the cross-sectional wage equation (Gannon and Nolan, 2004). However, results obtained in this way should not be over-interpreted, particularly because there are in some cases only a small number of firms in a given sector in the data. In addition, it is not clear from a theoretical perspective how such firm effects might be interpreted. Goux and Maurin (1999) mention firm size as important, for example, but that is already included separately as a control variable in our model. 
those for the Netherlands) ${ }^{10}$ are in line with the literature (see, for example, Albaek et al., 1996 for Norway; Rycx, 2002 and Plasman et al., 2006 for Belgium; Hartog et al., 2000 for Portugal; and Casado-Diaz and Simón, 2007 for Spain). We find indeed that the structure of inter-industry wage differentials is relatively compressed in Norway and Belgium and fairly dispersed in Italy, Spain and (in particular) Portugal. Results for Eastern European countries are remarkable. Indeed, they indicate that the dispersion of inter-industry wage differentials in the Czech Republic or Poland is of the same order of magnitude as in Southern European countries, that is, comparable to figures recorded for the Anglo-Saxon countries. ${ }^{11}$ As regards Latvia, Lithuania and Slovakia, we find that the dispersion of industry wage premia is well above those reported for Western European countries and even for the Anglo-American world. ${ }^{12}$

\section{Table 6: Dispersion of inter-industry wage differentials and collective bargaining characteristics}

\begin{tabular}{|c|c|c|c|c|c|}
\hline & WASD $^{a}$ & $\begin{array}{c}\text { Degree of } \\
\text { centralisation }\end{array}$ & $\begin{array}{c}\text { Degree of } \\
\text { coordination }\end{array}$ & $\begin{array}{c}\text { Unions } \\
\text { coverage rate }\end{array}$ & $\begin{array}{c}\text { Union } \\
\text { density }\end{array}$ \\
\hline $\mathbf{N O}^{\mathbf{b}}$ & 0.074 & I & 4.5 & 70 & 54 \\
\hline BE & 0.076 & 0.61 & 4 & 96 & 69 \\
\hline ES & 0.101 & 0.38 & 3 & 81 & 15 \\
\hline NL & 0.103 & 0.58 & 4 & 81 & 25 \\
\hline IT & 0.121 & 0.34 & 2.5 & 70 & 35 \\
\hline $\mathbf{C Z}$ & 0.123 & 0.27 & 1 & 35 & 30 \\
\hline PT & 0.137 & 0.30 & 2 & 87 & 30 \\
\hline SK & 0.161 & 0.33 & 2 & 50 & 35 \\
\hline LT & 0.162 & 0.23 & 1 & 15 & 15 \\
\hline
\end{tabular}

${ }^{10}$ Our findings show that the dispersion of inter-industry wage differentials is relatively big in the Netherlands; that is, of the same order of magnitude as in Spain. However, according to Hartog et al. (1997) and Teulings and Hartog (1998), results for the Netherlands would be substantially smaller (that is, slightly higher than those recorded for the Scandinavian countries).

${ }^{11}$ For a comparison of the dispersion of inter-industry wage differentials in Southern European and Anglo-Saxon countries see, for example, Hartog et al. (2000), Casado-Diaz and Simón (2007) and Gannon et al. (2007).

12 It is important to note that the data only refer to establishments with 10 or more workers. This limitation may be prejudicial since low pay prevails in small firms (Lucifora et al., 2005). One might generally expect that inter-industry wage differentials differ by firm size. For instance, smaller firms are likely to have less detailed job descriptions and no seniority-based automatic wage adjustments. This may lead to a smaller bandwidth of wage differences in these firms. Alternatively, there is a large body of empirical evidence supporting the existence of firm-size wage differentials (Oi and Idson, 1999; Lallemand et al., 2007). If firms of different sizes are not distributed uniformly over industries, this might bias the results (although the main effects will be picked up by the inclusion of firm size in the wage equation). Overall, whether the omission of small firms leads to an over- or underestimation of the true dispersion of inter-industry wage differentials remains an open question. For example, Rycx (2002) cites results calculated on Dutch data (Loonstructuuronderzoek) that, excluding firms with fewer than 10 employees, reduce the dispersion of the industry wage differentials (estimated for 23 sectors) for 1996 and 1997 by 6\% and 5\% respectively. These findings suggest that differences in the weighted-adjusted standard deviation due to the omission of small establishments are noteworthy, but not that large. The proportion of all employees working in establishments with fewer than 10 employees is different across countries, so it is unclear whether this conclusion also holds for other European countries. 


\begin{tabular}{|l|c|c|c|c|c|}
\hline LV & 0.180 & 0.30 & 1.5 & 20 & 30 \\
\hline PL & 0.127 & $/$ & 1 & 45 & 15 \\
\hline $\begin{array}{l}\text { Correlations } \\
\text { (with WASD) }\end{array}$ & & $-0.76^{*}$ & $-0.79^{* *}$ & $-0.75^{*}$ & $-0.53^{\circ}$ \\
\hline
\end{tabular}

${ }^{a}$ Weighted adjusted standard deviation of industry wage differentials. ${ }^{b}$ All information on collective bargaining characteristics in Norway are taken from OECD (2004). ${ }^{\mathrm{c}}$ EIRO (2004). ${ }^{\mathrm{d}}$ EIRO (2007). ${ }^{\mathrm{e}}$ European Commission (2004). The degree of centralisation is measured as in Iversen (1999). A large value is associated with a highly centralised country. The scale ranges between 0 (at the limit) and 1 . The degree of coordination: $5=$ explicit coordination between and within peak associations of unions and employers, through agreements at the national and sectoral level; $4=$ explicit coordination between peak federations through agreements only at the national level or implicit coordination (without agreement) within confederations (unions or employers) at the national and sectoral level; $3=$ implicit coordination through synchronisation of sectoral bargaining and patternsetting; 2 = implicit coordination and irregular or incomplete pattern-setting; $1=$ no coordination at the national or sectoral level. $* * / * / 0$ : Coefficient significant at the 1,5 and 10 per cent level, respectively.

Several arguments could be put forward for these differences across countries. Teulings and Hartog (1998) argued that countries with lower dispersion have a higher degree of corporatism. We test this hypothesis by examining the correlation between the dispersion of inter-industry wage differentials and collective bargaining characteristics, that is, the degree of centralisation, the degree of coordination among the social partners, the trade union coverage rate and trade union density. ${ }^{13}$ Results, reported in Table 6, show the existence of a significant and negative relationship between the WASD of the net inter-industry wage differentials and all collective bargaining characteristics under consideration. In Eastern European countries, the data reflect much less centralisation and coordination compared to Belgium and Norway, and also show higher dispersion in the former countries. Indeed, results from the simple correlation coefficients suggest that industry wage differentials are more dispersed in countries where wage bargaining is weakly coordinated and essentially organised at the firm or establishment level. Moreover, findings indicate that the inter-industry wage structure tends to be less compressed when the proportion of workers covered by a collective agreement is relatively small (namely in Eastern European countries). The same type of relationship, albeit less strong and significant, is found with trade union density. Overall, our results fit in well with findings from earlier studies on the existence of a negative relationship between the dispersion of inter-industry wage differentials and the degree of corporatism (Hartog et al., 1997; Kahn, 1998; Rycx, 2002; Gannon et al., 2007).

\section{Conclusion}

In this paper, we compared the structure and determinants of inter-industry wage differentials in Eastern and Western European countries (Belgium, Italy, the Netherlands, Norway, Portugal and Spain compared with Latvia, Lithuania, the Czech Republic, Slovakia and Poland). To do so, we used a unique harmonised, linked

13 The degree of centralisation refers strictly to the principal level at which bargaining occurs (establishment, firm, industry or national level). In contrast, the degree of coordination among the social partners refers to the ability of trade unions and employers' organisations to coordinate their decisions both horizontally (within a given bargaining level) and vertically (between different bargaining levels). Coordination might be 'overt' or 'covert'. Overt or direct coordination refers to the explicit pursuit of economy-wide coordination goals by the principal bargaining agents (that is, peak associations of business and labour, possibly joined by the government agencies in tripartite arrangements). In contrast, covert or indirect coordination is achieved through the internal governance of the associations and/or through the pace-setting role of bargaining in key sectors (for a more detailed discussion see, for example, OECD 1997, 2004). 
employer-employee data set, the 2002 European Structure of Earnings Survey. This survey contains detailed information, provided by the management of establishments, both on individual workers (for example, gross hourly wages, bonuses, age, education, tenure, sex, occupation, employment contract, working time) and employers' characteristics (for example, sector of activity, size of establishment, level of wage bargaining, region). Although the effect of sectoral affiliation on workers' wages has been a topic of great interest, the evidence for Eastern European countries is scarce (Chase, 1998; Newell, 2001; Geishecker and Haisken-DeNew, 2002). Moreover, little is known on how inter-industry wage structures differ between Eastern and Western European countries.

Empirical findings, reported in this paper, show the existence of substantial differences in earnings across sectors in all countries, even when controlling for a wide range of employee, job and employer characteristics. They also indicate that the hierarchy of sectors in terms of wages is quite similar in Eastern and Western European countries. Among high-wage sectors, we find the energy (coke, petroleum, gas, electricity and nuclear power), chemical, financial and computer industries. In contrast, it is in the traditional sectors (wood and cork industry, textile, clothing and leather industry, hotels and restaurants, and retailing) that wages are lowest. Further results show that the dispersion of inter-industry wage differentials fluctuates considerably across countries. In line with the literature, we find that the structure of inter-industry wage differentials is relatively compressed in Norway and Belgium and fairly dispersed in Italy, Spain and (in particular) Portugal. Results for Eastern European countries are remarkable. Indeed, they show that the dispersion of inter-industry wage differentials in the Czech Republic is of the same order of magnitude as in Southern European countries, that is, comparable to figures recorded for the Anglo-Saxon countries. As regards Latvia, Lithuania and Slovakia, we find that the dispersion of industry wage premia is well above those reported for Western European countries and even for the Anglo-American world. To understand these differences across countries, we examined the correlation between the dispersion of industry wage premia and collective bargaining characteristics. Results suggest that inter-industry wage differentials are more dispersed in countries where wage bargaining is weakly coordinated and essentially organised at the firm or establishment level. They also indicate that the wage structure is more compressed in countries where the proportion of workers covered by a collective agreement or affiliated to a trade union is high. Our findings thus support the hypothesis of a negative relationship between the dispersion of inter-industry wage differentials and a country's degree of corporatism.

\section{References}

Abowd, J., F. Kramarz, and D. Margolis (1999), 'High wages workers and high wages firms', Econometrica, 67, pp. 251-335.

Arai, M., G. Ballot and A. Skalli (1996), 'Différentiels intersectoriels de salaire et caractéristiques des employeurs en France’, Economie et Statistique, 99, pp. 37-58.

Benito, A. (2000), 'Inter-industry wage differentials in Great Britain', Oxford Bulletin of Economics and Statistics, 62, pp. 727-746.

Björklund, A., B. Bratsberg, T. Eriksson, M. Jäntti and O. Raaum (2007), 'Inter-industry wage differentials and unobserved ability: siblings evidence from five countries', Industrial Relations, 46, pp. 171-202. 
Boeri, T. and M. Keese (1992), 'Labour markets and the transition in Central and Eastern Europe’, OECD Economic Studies, No. 18.

Casado-Diaz, J. and H. Simón (2007), 'Industry wage premia and collective bargaining revisited: evidence from Spain', (forthcoming in Applied Economics Letters).

Chase, R. (1998), 'Markets for communist human capital: returns to education and experience in the Czech Republic and Slovakia', Industrial and Labor Relations Review, 51, pp. 401-423.

Derek, C. and S. Ilayperuma (2005), 'Wage determination under plan and early transition: Bulgarian evidence using matched employer-employee data', Journal of Comparative Economics, 33, pp. 227-243.

Edin, P-A. and J. Zetterberg (1992), 'Interindustry wage differentials: evidence from Sweden and a comparison with the United States', American Economic Review, 82, pp. 1341-1349.

EIRO (2002), 'Industrial relations in the EU Member States and candidate countries', European Foundation for the Improvement of Living and Working Conditions, EIROnline, http://www.eurofound.europa.eu/eiro/2002/07/feature/tn0207104f.htm.

EIRO (2004), 'Industrial relations in the EU, Japan and USA, 2002', European Foundation for the Improvement of Living and Working Conditions, EIROnline, http://www.eurofound.europa.eu/eiro/2004/01/feature/tn0401101f.htm.

EIRO (2007), 'Industrial relations in EU Member States 2000-2004', European Foundation for the Improvement of Living and Working Conditions, EIROnline, http://www.eurofound.europa.eu/pubdocs/2007/15/en/1/ef0715en.pdf.

Erdil, E. and H. Yetkiner (2001), 'A comparative analysis of inter-industry wage differentials: industrialized versus developing countries’, Applied Economics, 33, pp. 1639-1648.

European Commission (2004), Industrial relations in Europe 2004, Employment and Social Affairs, Luxembourg.

Ferro-Luzzi, G. (1994), 'Inter-industry wage differentials in Switzerland', Swiss Journal of Economics and Statistics, 130, pp. 421-443.

Fleisher, B., P. Sabrianova and W. Xiaojun ( 2004), 'Returns to skills and the speed of reforms: evidence from Central and Eastern Europe, China and Russia', William Davidson Institute Working Paper, No. 703.

Flek, V. (1996), 'Wage and employment restructuring in the Czech Republic', Working Paper of the Czech National Bank, No. 60.

Flek, V. and J. Vecernik, (1998) 'Employment and wage structures in the Czech Republic', Working Paper of the Czech National Bank, No. 3.

Flemming, J. and J. Micklewright (1999), 'Income distribution, economic systems and transition’, Innocenti Occasional Papers, No. 70.

Gannon, B. and B. Nolan (2004), 'Inter-industry wage differentials in Ireland', Economic and Social Review, 35, pp. 157-182.

Gannon, B., R. Plasman, F. Rycx and I. Tojerow (2007), 'Inter-Industry Wage Differentials and the Gender Wage Gap: Evidence from European Countries', Economic and Social Review, 38, pp. 135-155.

Geishecker, I. and J. Haisken-DeNew (2002), 'Riding the transition roller-coaster: flexibility and the inter-industry wage structure in Russia’, DIW Discussion Paper, No. 280.

Gibbons, R. and L. Katz (1992), 'Does unmeasured ability explain interindustry wage differentials ?', Review of Economic Studies, 59, pp. 515-535.

Gittleman, M. and E. Wolff (1993), 'International comparisons of inter-industry wage differentials’, Review of Income and Wealth, 39, pp. 295-312. 
Goux, D. and E. Maurin (1999), 'Persistence of interindustry wage differentials: a re-examination using matched worker-firm panel data', Journal of Labor Economics, 17, pp. 492-533.

Haisken-DeNew, J. and C. Schmidt (1997), 'Interindustry and interregion differentials: mechanics and interpretation', Review of Economics and Statistics, 79, pp. 516-521.

Hartog, J., P. Pereira and J. Vieira (2000), 'Inter-industry wage dispersion in Portugal', Empirica, 27, pp. 353-364.

Hartog, J., R. Van Opstal and C. Teulings (1997), 'Inter-industry wage differentials and tenure effects in the Netherlands and the U.S.', De Economist, 145, pp. 91-99.

Helwege, J. (1992), 'Sectoral shifts and interindustry wage differentials', Journal of Labor Economics, 10, pp. 55-84.

Kahn, L. (1998), 'Collective bargaining and the interindustry wage structure: international evidence’, Economica, 65, pp. 507-534.

Kouwenberg, J. and R. van Opstal (1999), 'Inter-industry wage differentials: evidence from micro data', Quarterly Review of CPB Netherlands Bureau for Economic Policy Analysis, 3, pp. 26-29.

Krueger, A. and L. Summers (1988), 'Efficiency wages and the inter-industry wage structure', Econometrica, 56, pp. 259-294.

Lallemand, T., R. Plasman and F. Rycx (2007), 'The establishment-size wage premium: evidence from European countries', Empirica, 34, pp. 427-451.

Lucifora, C. (1993), 'Inter-industry and occupational wage differentials in Italy', Applied Economics, 25, pp. 1113-1124.

Lucifora, C., A. McKnight and W. Salverda (2005), 'Low-wage employment in Europe: a review of the evidence', Socio-Economic Review, 3, pp. 259-292.

Martins, P. (2004), 'Industry wage premia: evidence from the wage distribution', Economics Letters, 83, pp. 157-163.

Newell, A. (2001), 'The distribution of wages in transition countries', IZA Discussion Paper, No. 267.

OECD (2004), Employment outlook 2004, Paris: OECD.

Oi, W. and T. Idson (1999), 'Firm size and wages', in O. Ashenfelter and D. Card (eds), Handbook of Labor Economics, 3B, Elsevier Science: North Holland, pp. 2165-2214.

Rycx, F. (2002), 'Inter-industry wage differentials: evidence from Belgium in a crossnational perspective’, De Economist, 150, pp. 555-568.

Plasman, R., F. Rycx and I. Tojerow (2006), 'Industry wage differentials, unobserved ability, and rent-sharing: evidence from matched worker-firm data, 1995-2002', IZA Discussion Paper, No. 2387.

Reilly, K. and L. Zanchi (2003), 'Industry wage differentials: how many, big and significant are they?', International Journal of Manpower, 24, pp. 367-398.

Stiglitz, J. (1974), 'Wage determination and unemployment in L.D.C.s: the labor turnover model’, Quarterly Journal of Economics, 88, pp. 194-227.

Teulings, C. and J. Hartog (1998), Corporatism or competition?, Cambridge: Cambridge University Press.

Thaler, R. (1989), 'Anomalies: interindustry wage differentials', Journal of Economic Perspectives, 3, pp. 181-193.

Vecernik, J. (2001), 'Earnings disparities in the Czech Republic: evidence of the past decade and cross-national comparison', William Davidson Institute Working Paper, No. 373.

Vecernik, J. (2001), 'Labour market flexibility and employment security in the Czech Republic’, International Labour Organization Employment Paper, No. 27. 
Vecernik, J. (2006), 'Evolution or revolution? Disparities in earnings and household income in the Czech Republic 1988-2002’, Institute of Economic Studies Occasional Paper.

White, H. (1980), 'A heteroscedasticity-consistent covariance matrix estimator and a direct test for heteroscedasticity’, Econometrica, 48, pp. 817-838.

Zanchi, L. (1998), 'Interindustry wage differentials in dummy variable models', Economics Letters, 60, pp. 297-301.

Zweimuller, J. and E. Barth (1994), 'Bargaining structure, wage determination and wage dispersion in 6 OECD countries’, Kyklos, 47, pp. 81-93. 


\section{Appendix 1: Gross inter-industry wage differentials}

(i.e. estimated without control variables), in percentage terms

\begin{tabular}{|c|c|c|c|c|c|c|c|c|c|c|c|}
\hline & $\mathbf{C Z}$ & $\mathbf{L V}$ & $\mathbf{L T}$ & SK & PL & BE & IT & NL & NO & PT & ES \\
\hline 10 Mining of coal and lignite, extraction of peat & 0.758 & 0.240 & 0.118 & 0.450 & -0.392 & -0.315 & -0.132 & - & 0.257 & - & 0.935 \\
\hline 11 Extraction of crude petroleum and natural gas & 0.508 & - & 3.156 & 0.943 & 1.558 & - & 0.633 & 1.788 & 0.939 & - & 1.542 \\
\hline 12 Mining of uranium and thorium ores & - & - & - & - & - & - & - & - & - & 0.639 & - \\
\hline 13 Mining of metal ores & - & - & - & -0.607 & 2.246 & - & - & - & 0.136 & -0.057 & 0.173 \\
\hline 14 Other mining and quarrying & 0.547 & 0.682 & 0.211 & 0.081 & 0.556 & -0.120 & -0.056 & 0.915 & 0.060 & -0.014 & -0.004 \\
\hline 15 Food products and beverages & -0.185 & - & -0.052 & -0.287 & -0.269 & - & -0.003 & 0.245 & -0.143 & -0.125 & -0.122 \\
\hline 16 Tobacco products & 2.157 & - & 4.459 & 0.561 & 1.626 & -0.082 & 0.571 & 0.814 & -0.027 & -0.123 & 1.083 \\
\hline 17 Textiles & -0.310 & 0.239 & 0.047 & -0.450 & -0.416 & -0.311 & -0.104 & 0.126 & -0.204 & -0.275 & -0.200 \\
\hline 18 Clothing & -0.593 & -0.274 & -0.213 & -0.421 & -1.078 & -0.227 & -0.335 & -0.199 & -0.288 & -0.476 & -0.459 \\
\hline 19 Leather & -0.540 & -0.574 & -0.090 & -0.460 & -0.833 & -0.216 & -0.275 & -0.114 & -0.198 & -0.429 & -0.443 \\
\hline 20 Wood and cork & -0.127 & -0.278 & -0.358 & -0.305 & -0.539 & -0.292 & -0.235 & 0.100 & -0.171 & -0.188 & -0.275 \\
\hline 21 Paper & 0.096 & 0.051 & 0.565 & 0.406 & 0.306 & -0.017 & 0.034 & 0.341 & -0.004 & 0.337 & 0.276 \\
\hline 22 Printing and publishing & -0.026 & - & 0.060 & -0.030 & 0.546 & 0.065 & 0.156 & 0.401 & 0.147 & 0.368 & 0.281 \\
\hline 23 Coke, refined petroleum products and nuclear fuel & 0.719 & - & 3.658 & 0.987 & 2.138 & 0.475 & 0.463 & 1.666 & 0.747 & - & 1.886 \\
\hline 24 Chemical and chemical products & 0.223 & 0.381 & 0.726 & 0.122 & 0.887 & 0.254 & 0.317 & 0.778 & 0.272 & 0.746 & 0.657 \\
\hline 25 Rubber and plastic products & 0.065 & -0.241 & -0.049 & 0.238 & 0.098 & -0.078 & -0.064 & 0.152 & -0.093 & -0.077 & 0.183 \\
\hline 26 Other non-metallic mineral products & 0.111 & 0.195 & 0.197 & -0.092 & 0.171 & -0.052 & -0.027 & 0.332 & -0.026 & 0.091 & 0.104 \\
\hline 27 Basic metals & 0.148 & 0.879 & 0.444 & 0.682 & 0.512 & 0.046 & 0.031 & 0.582 & 0.128 & 0.173 & 0.605 \\
\hline 28 Fabricated metal products & -0.033 & -0.054 & -0.153 & -0.168 & -0.024 & -0.149 & -0.083 & -0.023 & -0.051 & -0.083 & 0.015 \\
\hline 29 Machinery and equipment & 0.029 & 0.116 & 0.305 & -0.108 & 0.277 & 0.004 & 0.030 & 0.459 & 0.057 & 0.141 & 0.227 \\
\hline 30 Office machinery and computers & -0.195 & 0.707 & -0.373 & -0.158 & - & -0.143 & 0.012 & 0.445 & 0.179 & - & 0.577 \\
\hline 31 Electrical machinery and apparatus & -0.139 & 0.426 & 0.453 & -0.245 & 0.250 & -0.002 & -0.014 & 0.251 & 0.125 & 0.182 & 0.179 \\
\hline 32 Radio, television and communication equipment & -0.176 & -0.278 & 0.470 & -0.457 & 0.801 & 0.249 & 0.099 & 0.544 & 0.207 & 0.426 & 0.224 \\
\hline $\begin{array}{l}33 \text { Medical, precision and optical instruments, watches } \\
\text { and clocks }\end{array}$ & -0.249 & 0.167 & 0.384 & 0.141 & 0.421 & -0.099 & 0.042 & 0.224 & 0.265 & 0.208 & 0.407 \\
\hline 34 Motor vehicles, trailers and semi-trailers & 0.315 & 0.019 & 0.009 & 0.726 & 0.402 & 0.009 & 0.005 & 0.216 & -0.025 & 0.163 & 0.468 \\
\hline 35 Other transport equipment & 0.115 & 0.442 & 0.858 & 0.164 & 0.495 & 0.011 & -0.030 & 0.242 & 0.079 & 0.399 & 0.334 \\
\hline 36 Furniture, manufacturing & -0.232 & -0.121 & -0.154 & -0.436 & -0.416 & -0.295 & -0.244 & -0.160 & -0.136 & -0.332 & -0.253 \\
\hline 37 Recycling & -0.172 & -0.354 & -0.235 & -0.400 & 0.113 & -0.330 & -0.212 & -0.194 & -0.049 & -0.091 & 0.034 \\
\hline 40 Electricity, gas, steam and hot water supply & 0.370 & 1.926 & 0.821 & 0.845 & 0.941 & 0.698 & 0.511 & 0.629 & 0.028 & 2.086 & 1.761 \\
\hline 41 Collection, purification and distribution of water & 0.244 & - & -0.216 & -0.025 & 0.674 & - & 0.280 & 0.887 & - & 0.897 & 0.245 \\
\hline 45 Construction & -0.080 & -0.242 & -0.269 & -0.357 & -0.122 & -0.210 & -0.161 & 0.102 & -0.005 & -0.166 & -0.264 \\
\hline $\begin{array}{l}50 \text { Sale, maintenance and repair of motor vehicles and } \\
\text { motorcycles }\end{array}$ & -0.093 & -0.205 & - & -0.045 & 0.020 & -0.029 & -0.060 & -0.133 & -0.113 & 0.045 & -0.030 \\
\hline 51 Wholesale trade & 0.050 & -0.094 & 0.153 & -0.079 & 0.076 & 0.055 & 0.060 & 0.064 & 0.111 & 0.150 & -0.010 \\
\hline 52 Retail trade & -0.441 & -0.454 & -0.285 & -0.241 & -0.637 & -0.254 & -0.104 & -0.596 & -0.338 & -0.365 & -0.294 \\
\hline 55 Hotels and restaurants & -0.477 & -0.487 & -0.493 & -0.340 & -0.539 & -0.486 & -0.278 & -0.563 & -0.337 & -0.425 & -0.340 \\
\hline 60 Land transport; transport via pipelines & 0.004 & -0.393 & -0.520 & -0.541 & -0.049 & -0.381 & -0.033 & -0.238 & -0.146 & 0.028 & -0.112 \\
\hline 61 Water transport & - & 1.539 & 1.200 & - & 2.226 & -0.069 & 0.301 & 0.451 & 0.100 & 0.680 & - \\
\hline 62 Air transport & 3.568 & 0.330 & 0.075 & 0.091 & 1.763 & 0.104 & 0.427 & 0.590 & 0.356 & 1.057 & 0.899 \\
\hline 63 Transport activities & 0.158 & 0.606 & 0.267 & 0.485 & 0.438 & -0.133 & 0.014 & 0.076 & -0.053 & 0.710 & -0.022 \\
\hline 64 Post and telecommunications & 1.620 & 3.284 & 1.468 & -0.144 & 1.959 & 0.186 & -0.291 & 0.068 & 0.218 & 1.984 & 1.156 \\
\hline 65 Financial intermediation & 1.072 & 2.417 & 1.686 & 0.586 & 1.425 & 0.437 & 0.960 & 0.893 & 0.203 & 1.840 & 1.633 \\
\hline 66 Insurance and pension funding & 0.799 & 1.149 & 0.605 & 1.101 & 1.504 & 0.346 & 0.631 & 0.729 & 0.254 & 2.028 & 0.759 \\
\hline 67 Activities auxiliary to financial intermediation & 1.295 & 0.010 & -0.204 & 0.280 & 0.806 & 0.335 & 0.212 & 0.443 & 0.682 & 1.529 & 0.663 \\
\hline 70 Real estate activities & 0.114 & -0.230 & -0.098 & 0.849 & 0.377 & -0.156 & 0.021 & 0.721 & 0.064 & 0.105 & -0.038 \\
\hline 71 Renting of machinery & 1.231 & 1.383 & -0.095 & 0.105 & 1.139 & -0.031 & 0.071 & -0.220 & -0.112 & 0.162 & -0.302 \\
\hline 72 Computer and related activities & 0.341 & 1.661 & 0.524 & 0.309 & 1.690 & 0.255 & 0.258 & 0.676 & 0.545 & 1.401 & 0.234 \\
\hline 73 Research and development & 0.192 & 0.141 & -0.098 & 0.966 & 1.181 & 0.209 & 0.181 & 0.869 & 0.367 & 0.895 & 0.623 \\
\hline 74 Other businesses activities & -0.244 & 0.005 & -0.171 & 0.495 & -0.392 & -0.151 & -0.177 & -0.426 & 0.040 & 0.193 & -0.306 \\
\hline
\end{tabular}


Appendix 2: Spearman correlation coefficients between gross interindustry wage differentials

(i.e. estimated without control variables)

\begin{tabular}{|c|c|c|c|c|c|c|c|c|c|c|c|}
\hline & $\mathbf{C Z}$ & LV & LT & SK & PL & BE & IT & NL & NO & PT & ES \\
\hline $\mathrm{CZ}$ & 1.000 & & & & & & & & & & \\
\hline LV & $0.627^{* *}$ & 1.000 & & & & & & & & & \\
\hline LT & $0.516^{* *}$ & $0.756^{* *}$ & 1.000 & & & & & & & & \\
\hline SK & $0.745^{* *}$ & $0.670^{* *}$ & $0.600 * *$ & 1.000 & & & & & & & \\
\hline PL & $0.776^{* *}$ & $0.757^{* *}$ & $0.746^{* *}$ & $0.557^{* *}$ & 1.000 & & & & & & \\
\hline BE & $0.517^{* *}$ & $0.632^{* *}$ & $0.605^{* *}$ & $0.696^{* *}$ & $0.71^{* *}$ & 1.000 & & & & & \\
\hline IT & $0.611^{* *}$ & $0.556^{* *}$ & $0.632 * *$ & $0.694^{* *}$ & $0.876^{* *}$ & $0.744^{* *}$ & 1.000 & & & & \\
\hline NL & $0.524^{* *}$ & $0.519^{* *}$ & $0.656^{* *}$ & $0.647^{* *}$ & $0.757^{* *}$ & $0.715^{* *}$ & $0.753^{* *}$ & 1.000 & & & \\
\hline NO & $0.554^{* *}$ & $0.505^{* *}$ & $0.548^{* *}$ & $0.651^{* *}$ & $0.668^{* *}$ & $0.717^{* *}$ & $0.633^{* *}$ & $0.785^{* *}$ & 1.000 & & \\
\hline PT & $0.649^{* *}$ & $0.771^{* *}$ & $0.463^{* *}$ & $0.728^{* *}$ & $0.654^{* *}$ & $0.858^{* *}$ & $0.698^{* *}$ & $0.600 * *$ & $0.779 * *$ & 1.000 & \\
\hline ES & $0.679 * *$ & $0.680^{* *}$ & $0.732 * *$ & $0.784^{* *}$ & $0.748 * *$ & $0.742 * *$ & $0.753^{* *}$ & $0.768^{* *}$ & $0.753 * *$ & $0.803^{* *}$ & 1.000 \\
\hline
\end{tabular}

$* * / * / 0$ : Coefficient significant at the 1,5 and 10 per cent level, respectively. 


\section{Appendix 3: Net inter-industry wage differentials}

(i.e. controlling for employee, job and employer characteristics, except the level of wage bargaining), in percentage terms

\begin{tabular}{|c|c|c|c|c|c|c|c|c|c|c|c|}
\hline & $\mathbf{C Z}$ & LV & LT & SK & PL & BE & IT & NL & NO & PT & ES \\
\hline 10 Mining of coal and lignite, extraction of peat & 0.390 & 0.562 & 0.194 & -0.029 & -0.394 & -0.180 & -0.210 & - & 0.142 & - & 0.584 \\
\hline $\begin{array}{l}11 \text { Extraction of crude petroleum and natural } \\
\text { gas }\end{array}$ & 0.035 & - & 2.164 & 0.415 & 2.438 & - & 0.287 & 0.442 & 0.494 & - & 0.222 \\
\hline 12 Mining of uranium and thorium ores & - & - & - & - & - & - & - & - & - & -0.139 & - \\
\hline 13 Mining of metal ores & - & - & - & -0.500 & 2.920 & - & - & - & 0.088 & 0.010 & -0.247 \\
\hline 14 Other mining and quarrying & 0.348 & 0.557 & 0.314 & 0.239 & 0.704 & 0.002 & 0.027 & 0.112 & 0.081 & 0.064 & 0.146 \\
\hline 15 Food products and beverages & -0.044 & - & -0.071 & -0.142 & -0.246 & - & 0.053 & 0.070 & -0.030 & -0.065 & -0.076 \\
\hline 16 Tobacco products & 0.899 & - & 1.664 & 0.445 & 1.645 & 0.040 & 0.261 & 0.070 & -0.033 & 0.044 & 0.312 \\
\hline 17 Textiles & -0.136 & -0.137 & -0.128 & -0.203 & -0.591 & -0.128 & -0.034 & -0.126 & -0.089 & -0.175 & -0.147 \\
\hline 18 Clothing & -0.247 & -0.105 & -0.107 & -0.146 & -1.083 & -0.090 & -0.112 & -0.174 & -0.142 & -0.211 & -0.148 \\
\hline 19 Leather & -0.320 & -0.248 & -0.144 & -0.158 & -0.591 & -0.117 & -0.119 & -0.135 & -0.087 & -0.140 & -0.169 \\
\hline 20 Wood and cork & -0.021 & -0.113 & -0.140 & -0.083 & -0.591 & -0.134 & -0.122 & -0.114 & -0.110 & -0.031 & -0.124 \\
\hline 21 Paper & 0.143 & 0.070 & 0.294 & 0.174 & 0.355 & 0.050 & 0.025 & 0.019 & -0.038 & 0.112 & 0.030 \\
\hline 22 Printing and publishing & 0.044 & - & 0.021 & 0.021 & 0.557 & 0.044 & 0.115 & 0.040 & 0.049 & 0.138 & 0.056 \\
\hline $\begin{array}{l}23 \text { Coke, refined petroleum products and } \\
\text { nuclear fuel }\end{array}$ & 0.304 & - & 1.186 & 0.649 & 1.788 & 0.194 & 0.249 & 0.259 & 0.155 & - & 0.412 \\
\hline 24 Chemical and chemical products & 0.053 & -0.001 & 0.172 & -0.119 & 0.749 & 0.116 & 0.120 & 0.073 & 0.068 & 0.280 & 0.150 \\
\hline 25 Rubber and plastic products & 0.170 & -0.083 & 0.089 & 0.124 & 0.291 & -0.041 & -0.025 & -0.073 & -0.052 & -0.042 & 0.067 \\
\hline 26 Other non-metallic mineral products & 0.125 & 0.136 & 0.107 & -0.076 & 0.207 & 0.005 & 0.016 & -0.056 & -0.021 & 0.061 & 0.066 \\
\hline 27 Basic metals & 0.009 & -0.186 & -0.145 & 0.256 & 0.197 & -0.012 & 0.025 & 0.048 & 0.053 & -0.010 & 0.100 \\
\hline 28 Fabricated metal products & -0.015 & -0.006 & -0.061 & -0.088 & -0.246 & -0.045 & 0.002 & -0.008 & -0.032 & -0.002 & 0.026 \\
\hline 29 Machinery and equipment & -0.091 & -0.201 & -0.081 & -0.076 & 0.005 & -0.008 & 0.030 & 0.000 & 0.010 & 0.046 & 0.041 \\
\hline 30 Office machinery and computers & -0.199 & 0.825 & -0.232 & 0.095 & - & -0.121 & -0.029 & -0.094 & -0.015 & - & -0.074 \\
\hline 31 Electrical machinery and apparatus & -0.040 & 0.004 & 0.087 & -0.090 & -0.098 & -0.027 & -0.019 & -0.097 & 0.037 & 0.043 & 0.013 \\
\hline $\begin{array}{l}32 \text { Radio, television and communication } \\
\text { equipment }\end{array}$ & -0.024 & -0.128 & -0.078 & -0.348 & 0.699 & 0.084 & -0.016 & 0.014 & 0.025 & 0.047 & 0.012 \\
\hline $\begin{array}{l}33 \text { Medical, precision and optical instruments, } \\
\text { watches and clocks }\end{array}$ & -0.162 & -0.101 & 0.153 & 0.011 & 0.236 & -0.042 & -0.009 & -0.129 & 0.059 & -0.151 & -0.025 \\
\hline 34 Motor vehicles, trailers and semi-trailers & 0.248 & 0.030 & -0.014 & 0.612 & 0.138 & 0.007 & -0.009 & -0.021 & -0.039 & 0.093 & 0.055 \\
\hline 35 Other transport equipment & -0.063 & 0.002 & 0.245 & -0.010 & 0.133 & -0.066 & -0.066 & -0.023 & 0.014 & 0.125 & 0.043 \\
\hline 36 Furniture, manufacturing & -0.093 & -0.020 & -0.111 & -0.140 & -0.345 & -0.152 & -0.116 & -0.228 & -0.051 & -0.138 & -0.103 \\
\hline 37 Recycling & -0.146 & -0.037 & -0.024 & -0.281 & 0.300 & -0.085 & -0.061 & -0.225 & 0.028 & 0.152 & 0.119 \\
\hline 40 Electricity, gas, steam and hot water supply & 0.133 & 0.352 & 0.282 & 0.246 & 1.088 & 0.354 & 0.177 & 0.102 & -0.073 & 0.553 & 0.374 \\
\hline $\begin{array}{l}41 \text { Collection, purification and distribution of } \\
\text { water }\end{array}$ & 0.028 & - & -0.122 & -0.066 & 0.818 & - & 0.137 & 0.150 & - & 0.329 & 0.050 \\
\hline 45 Construction & -0.059 & -0.112 & -0.035 & -0.173 & -0.197 & -0.056 & -0.029 & 0.068 & 0.042 & -0.044 & 0.075 \\
\hline $\begin{array}{l}50 \text { Sale, maintenance and repair of motor } \\
\text { vehicles and motorcycles }\end{array}$ & -0.067 & -0.019 & - & 0.162 & 0.310 & 0.007 & 0.009 & -0.004 & -0.050 & 0.042 & -0.032 \\
\hline 51 Wholesale trade & 0.091 & 0.066 & 0.171 & 0.056 & 0.128 & 0.008 & 0.035 & 0.019 & 0.003 & 0.050 & -0.014 \\
\hline 52 Retail trade & -0.235 & -0.200 & -0.079 & -0.004 & -0.788 & -0.057 & 0.002 & -0.051 & -0.123 & -0.152 & -0.111 \\
\hline 55 Hotels and restaurants & 0.013 & -0.047 & -0.108 & -0.037 & 0.276 & -0.211 & -0.137 & -0.006 & -0.037 & -0.209 & -0.085 \\
\hline 60 Land transport; transport via pipelines & -0.005 & -0.185 & -0.250 & -0.094 & -0.049 & -0.144 & 0.018 & -0.114 & -0.029 & 0.001 & 0.005 \\
\hline 61 Water transport & - & 1.215 & 0.160 & - & 3.521 & -0.030 & 0.189 & -0.044 & 0.010 & 0.289 & - \\
\hline 62 Air transport & 3.583 & 0.174 & 0.007 & -0.102 & 2.374 & 0.105 & 0.408 & 0.224 & 0.222 & 0.318 & 0.240 \\
\hline 63 Transport activities & 0.276 & 0.349 & 0.205 & 0.364 & 0.680 & -0.021 & 0.020 & 0.092 & -0.011 & 0.432 & 0.011 \\
\hline 64 Post and telecommunications & 0.848 & 1.835 & 0.615 & 0.029 & 1.709 & 0.036 & -0.355 & 0.097 & 0.090 & 0.764 & 0.172 \\
\hline
\end{tabular}




\begin{tabular}{|l|c|c|c|c|c|c|c|c|c|c|c|}
\hline 65 Financial intermediation & 0.245 & 0.758 & 0.584 & 0.085 & 1.492 & 0.075 & 0.378 & 0.312 & -0.060 & 0.649 & 0.368 \\
\hline 66 Insurance and pension funding & 0.308 & 0.054 & 0.366 & 0.479 & 1.285 & 0.093 & 0.209 & 0.172 & -0.061 & 0.498 & 0.040 \\
\hline $\begin{array}{l}\text { 67 Activities auxiliary to financial } \\
\text { intermediation }\end{array}$ & 0.771 & 0.131 & 0.154 & 0.086 & 0.591 & 0.025 & 0.091 & 0.419 & 0.298 & 0.596 & 0.153 \\
\hline 70 Real estate activities & 0.025 & 0.081 & 0.170 & 0.413 & 0.936 & -0.022 & 0.010 & 0.161 & 0.028 & 0.087 & 0.035 \\
\hline 71 Renting of machinery & 0.847 & 1.199 & 0.118 & 0.078 & 1.251 & 0.024 & 0.077 & -0.093 & -0.004 & 0.084 & -0.056 \\
\hline 72 Computer and related activities & -0.069 & 0.833 & 0.296 & 0.243 & 1.487 & -0.012 & 0.093 & 0.071 & 0.155 & 0.294 & -0.057 \\
\hline 73 Research and development & -0.135 & -0.122 & -0.048 & 0.389 & 0.729 & -0.034 & 0.015 & 0.104 & -0.082 & 0.390 & -0.104 \\
\hline 74 Other businesses activities & -0.083 & 0.213 & -0.014 & -0.113 & -0.098 & -0.029 & -0.129 & -0.151 & 0.023 & 0.186 & -0.113 \\
\hline
\end{tabular}

\section{Appendix 4: Spearman correlation coefficients between net inter- industry wage differentials}

(i.e. controlling for employee, job and employer characteristics, except the level of wage bargaining)

\begin{tabular}{|l|c|c|c|c|c|c|c|c|c|c|c|}
\hline & CZ & LV & LT & SK & PL & BE & IT & NL & NO & PT & ES \\
\hline \hline CZ & 1.000 & & & & & & & & & \\
LV & $0.455^{* *}$ & 1.000 & & & & & & & \\
LT & $0.351^{*}$ & $0.599^{* *}$ & 1.000 & & & & & & \\
SK & $0.529^{* *}$ & $0.485^{* *}$ & $0.615^{* *}$ & 1.000 & & & & & & \\
PL & $0.655^{* *}$ & $0.694^{* *}$ & $0.625^{* *}$ & $0.337^{* *}$ & 1.000 & & & & & \\
BE & $0.403^{* *}$ & 0.233 & $0.552^{* *}$ & $0.495^{* *}$ & $0.563^{* *}$ & 1.000 & & & \\
IT & $0.355^{*}$ & 0.016 & $0.405^{* *}$ & $0.520^{* *}$ & $0.584^{* *}$ & $0.601^{* *}$ & 1.000 & & & \\
NL & $0.478^{* *}$ & 0.267 & $0.590^{* *}$ & $0.594^{* *}$ & $0.638^{* *}$ & $0.621^{* *}$ & $0.591^{* *}$ & 1.000 & & \\
NO & $0.418^{* *}$ & $0.334^{*}$ & $0.515^{* *}$ & $0.316^{*}$ & $0.553^{* *}$ & 0.243 & $0.269^{\circ}$ & $0.610^{* *}$ & 1.000 & \\
PT & $0.482^{* *}$ & $0.625^{* *}$ & $0.481^{* *}$ & $0.414^{* *}$ & $0.616^{* *}$ & $0.646^{* *}$ & $0.312^{*}$ & $0.677^{* *}$ & $0.412^{* *}$ & 1.0000 \\
ES & $0.538^{* *}$ & $0.385^{*}$ & $0.616^{* *}$ & $0.572^{* *}$ & $0.363^{* *}$ & $0.504^{* *}$ & $0.376^{*}$ & $0.654^{* *}$ & $0.443^{* *}$ & $0.600^{* *}$ & 1.0000 \\
\hline
\end{tabular}

$* * / * / \%$ : Coefficient significant at the 1,5 and 10 per cent level, respectively. 